\title{
Use of Ground Penetrating Radar, Hydrogeochemical Testing, and Aquifer Characterization to Establish Shallow Groundwater Supply to the Rehabilitated Ni-les'tun Unit Floodplain: Bandon Marsh, Coquille Estuary, Oregon, USA
}

\author{
Curt D. Peterson ${ }^{1}$, Harry M. Jol ${ }^{2}$, David Percy ${ }^{1} \&$ Robert Perkins ${ }^{1}$ \\ ${ }^{1}$ Geology Department, Portland State University, Portland, United States \\ ${ }^{2}$ Department of Geography and Anthropology, University of Wisconsin Eau Claire, Eau Claire, United States \\ Correspondence: Curt Peterson, Geology Department, Portland State University, Portland, OR., 97207, United \\ States. Tel: 1-503-730-9266. E-mail: curt.d.peterson@gmail.com
}

Received: January 21, 2020

Accepted: March 26, 2020

Online Published: April 23, 2020

doi:10.5539/jgg.v12n1p25

URL: http://dx.doi.org/10.5539/jgg.v12n1p25

\begin{abstract}
Fluvial-tidal wetlands in the Ni-les'tun Unit ( 200 hectares) of the Bandon Marsh, Coquille Estuary, Oregon, were analyzed for shallow aquifer conditions that could influence surface water-qualities in reconstructed marsh, pond, and discharge/tidal channels. The wetlands were surveyed for pre-historic channel features, depth to groundwater surface (GWS), and subsurface salinity intrusion by ground penetrating radar (GPR) in 50 profiles, totaling 11.1 $\mathrm{km}$ in track line distance. Only small flood-discharge/tidal channel features $(<10 \mathrm{~m}$ width and $1-2 \mathrm{~m}$ depth) were recorded in the interior floodplain areas. GWS reflections were observed at 0.5-2.0 depth, where the GPR signal was not obscured by localized salinity intrusion $(\sim 0.5 \mathrm{~km}$ landward distance) from the adjacent Coquille Estuary channel. Top-sealed piezometers $(1.5-2.0 \mathrm{~m}$ depth) were installed at 10 sites, where in-situ groundwaters were monitored for temperature $\left(8.5-16.5^{\circ} \mathrm{C}\right)$, conductivity $\left(<100-18,800 \mu \mathrm{S} \mathrm{cm}^{-1}\right)$, and $\mathrm{pH}(2.5-7.8)$ on a seasonal basis. Dissolved oxygen was semi-quantitatively measured (ChemSticks) at some sites, and all sites were monitored (fall, winter, summer) for GWS level. Low dissolved oxygen $(\mathrm{DO}<1 \mathrm{ppm})$ at four sites was of particular concern for potential discharge into small channels that were to be constructed for juvenile salmonid nursery habitat. The horizontal and vertical asymmetries of conductivity (salinity), used as a conservative groundwater source tracer, and measured GWS elevation trends (gradients) led to a four-part flow model for shallow groundwater supply in the Ni-les'tun floodplain. Freshwater supplied, in part, by hillslope discharge contributes to low $\mathrm{pH}$ and low $\mathrm{DO}$ water quality in the shallow aquifer. Saline water, supplied by subsurface salinity intrusion and evaporative capillary rise, could introduce salinity toxicity to isolated (stagnant) surface ponds. Following construction of a dense channel network (2009-2011) by the Bandon Marsh National Wildlife Refuge, selected Ni-les'tun channel waters (13 sites) were monitored (2011-2012) for resulting water-quality. The tidally-connected channels generally showed improved water-quality relative to groundwater in some nearby piezometer sites. However, low-quality groundwater supply compromised some channel reaches (DO $\sim 2.0-4.7 \mathrm{ppm}$ ) that depended on groundwater recharge from hillslope discharge during either summer or winter conditions.
\end{abstract}

Keywords: Estuary, Floodplain, Groundwater, Hydrogeochemistry, Wetlands, Rehabilitation

\section{Introduction}

In this article, hydrogeomorphic analyses of the rehabilitated Ni-les'tun Unit of the Bandon Marsh National Wildlife Refuge (Figure 1) (USFWS, 2019a) are used to demonstrate relations between shallow groundwater conditions and surface wetland habitats. Wetlands in fluvial-tidal floodplain settings, such as the Ni-les'tun Unit, can be dependent on groundwater supply during periods of limited surface water recharge (Winter, 1995; Winter, 1999; Moore, 1999; Custodio, 2000). Though unseen from above, such shallow aquifer conditions can be important to supporting wildlife habitats in marshes, groundwater window ponds, and incised drainage/tidal channels (Krause et al., 2007; Meyer and Posey, 2009). Rehabilitation planning for previously diked, drained, and/or buried floodplains can benefit from understandings of the shallow aquifer and associated groundwater conditions that could influence the reconstructed floodplain habitats (Carol et al., 2013). In early planning for rehabilitation of the Ni-les'tun Unit (2003), ground penetrating radar (GPR) profiling and ground-truthing by auger 
gouge-coring were conducted throughout the study area ( 200 hectares) to establish 1) latest-prehistoric channel morphology, 2) subsurface depth of ground water surface (GWS), and 3) landward extents of subsurface salinity intrusion. Seasonal measurements of GWS depth and groundwater hydrogeochemistry (2005-2006) were obtained from sealed piezometers, which were strategically positioned in the Ni-les'tun floodplain. The porosity and hydraulic conductivity (permeability) of the shallow aquifer were constrained by permeameter analyses of remoulded geoprobe core samples. Rehabilitated drainage/tidal channels in the Ni-les'tun Unit floodplain were monitored for water-quality after initial channel network construction and storm/tide gate removal at tidal creek entrances (Beard, 2013). The depth of sandy soil saturation and corresponding standing water elevations in reconstructed drainage/tidal channels are locally dependent on the GWS elevation trends that extend under the $\mathrm{Ni}$ les'tun floodplain surface. The marshes and reconstructed channels in the Ni-les'tun Unit are influenced by recharge from hillslope runoff/interflow and subsurface saline water intrusion from the Coquille Estuary channel, as well as by direct precipitation on the floodplain and by Coquille River/Estuary overbank flooding. In this article, we focus on the integrated groundwater studies that were used to constrain the subsurface hydrogeomorphic conditions that could impact wetland habitats in the Ni-les'tun Unit floodplain. Such integrated groundwater studies should be applicable to other fluvial-tidal floodplains that are undergoing wetland rehabilitation for wildlife habitat, particularly in view of potential coastal wetland response to future climate change (Erwin, 2009; HerreraPantoja et al., 2012).

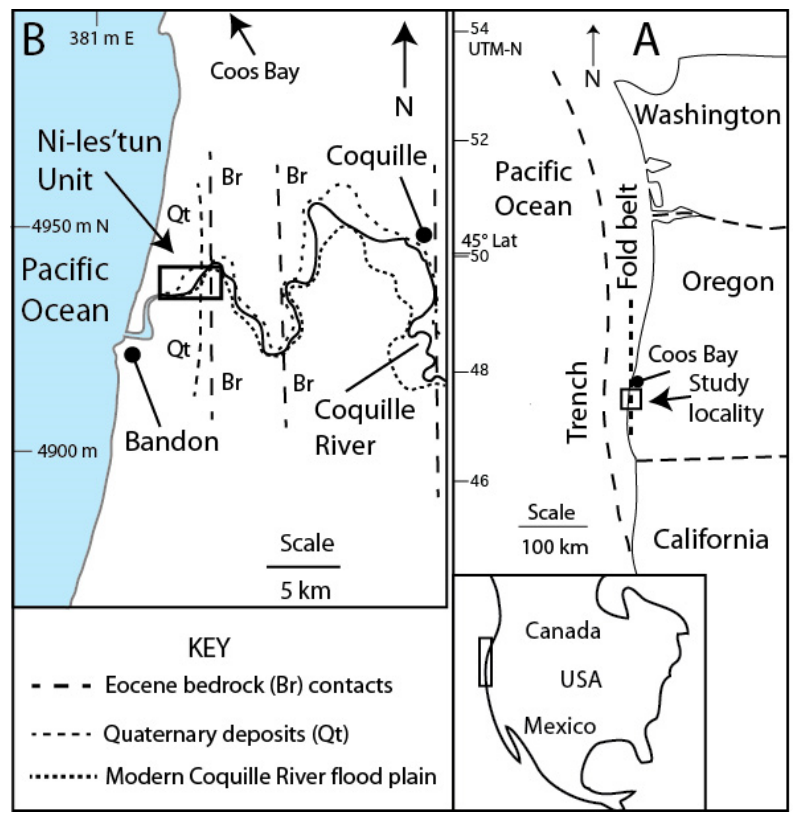

Figure 1. Location map of the study region

Map insets include (Part A) the Cascadia Subduction Zone (CSZ) trench (dashed line) and landward extent of the fold/fault belt (dotted line) (Peterson et al., 2012) and (Part B) the Ni-les'tun Unit (boxed) in the lower Coquille River Estuary. Bedrock (Br) contacts (dashed lines) (DOGAMI, 2019a) are shown landward of uplifted Quaternary marine terraces and overlying late-Pleistocene eolian dune-sheet deposits (Qt) (Peterson et al., 2007). Modern flood plain widths (dotted lines) reflect widths of the ancestral Coquille River valley, which is controlled, in part, by north-south aligned fold belt structures, as is also the case for Coos Bay tidal marshes to the north (Briggs, 1994).

\section{Background}

\subsection{Geomorphology of The Coquille Fluvial-Tidal Estuary}

The sinuous nature of the incised (ancestral) lower Coquille River valley is controlled by north-south striking upperplate structures and associated bedrock formation contacts, as developed in the Cascadia subduction zone fold/fault belt (Peterson et a., 2012) (Figure 1A). Incised valley widths and associated modern floodplain widths in the lower Coquille River valley are similarly influenced by the fold belt structural controls (Figure 1B). Freshwater creeks in fold axes valleys and groundwater from incised ancestral valley hillslopes discharge into the 
landward margins of the Coquille River/Estuary floodplains. The lowermost reaches of the Coquille River valley are incised into uplifted marine terraces (Baldwin et al., 1973) and overlying late-Pleistocene eolian dune deposits (Figure 2A), locally reaching several tens of meters in thickness (Peterson et al., 2007). Holocene dunes overlap the seaward-most extent of late-Pleistocene dune sheet, where they abut against the northwest corner of the Niles'tun Unit. The Ni-les'tun Unit floodplain is therefore bounded by upland Quaternary deposits to the north and the Coquille River/ Estuary channel to the south and east. The head of tide in the Coquille Estuary occurs about $60 \mathrm{~km}$ upriver from the river mouth. Elevated salinity levels extend about $20 \mathrm{~km}$ upriver during dry summer months, but are constrained to the lowest estuarine reaches by major river floods in winter months. Such floods deliver lithic-rich sub-angular river sand to the river mouth. The abundant river sediment supply has largely infilled the submerged ancestral Coquille River valley, leading to the extensive floodplain development throughout all but the lowermost-estuarine reaches. Latest-Holocene (3-0 ka) vertical accretion of the fluvial-tidal floodplains (Figure 2B) has kept pace with net sea-level rise $\left(\sim 1.0 \mathrm{~m} \mathrm{ka}^{-1}\right)$, as recorded in core site 521. However, alternating deposits of mud and muddy-peat in most of the older floodplain vibracore sections reflect neotectonic cycles of regional coastal interseismic uplift and coseismic subsidence (0.5-1.5 m paleo-tidal level change) in the southcentral Cascadia subduction zone (Briggs, 1994; Peterson et al., 2012). The muddy floodplain deposits are underlain by basal sand deposits, originating from lateral channel migrations in the upper- and middle-estuarine reaches (sites 511 and 521) and from tidal marsh progradation over tidal sand flats in the lowermost-estuarine reaches (site 508). The hydro-morphostratigraphy of the Ni-les'tun Unit floodplain is described in detail in later sections of this article.

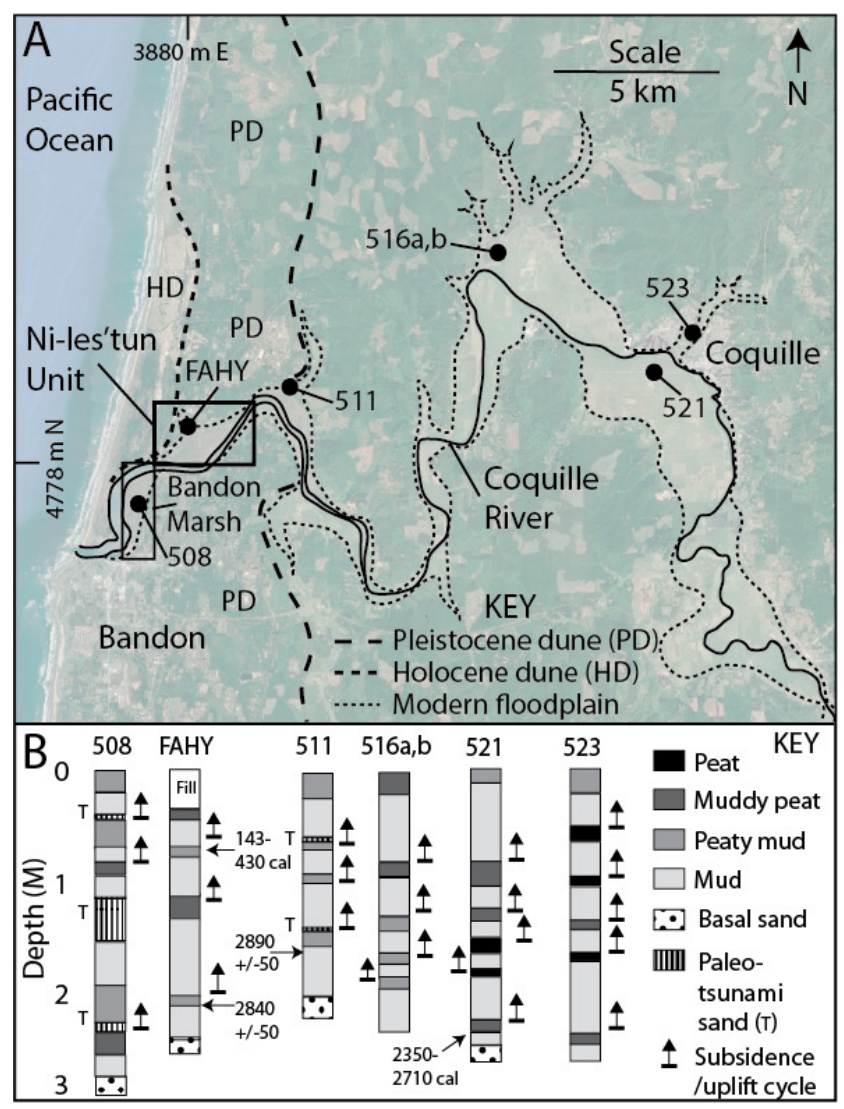

Figure 2. Floodplain development in the lower Coquille River valley

Part A. Map of modern floodplains (dotted lines) and selected vibracore sites (solid circles) in the lower Coquille River valley. The landward extents of the late-Pleistocene eolian dune sheet (PD) and overlapping Holocene dunes (HD) (Peterson et al., 2007) are shown relative to the Ni-les'tun Unit (boxed). Part B. Logs of recovered vibracores from selected floodplain sites in the lower Coquille River valley. Estimated coseismic subsidence events (arrows) range from $0.5-1.0 \mathrm{~m}$ in the lowermost river valley sites (508, FAHY) to $1.0-1.5 \mathrm{~m}$ in the more landward sites $(521,523)$ (Peterson et al., 2012). Redrafted vibracore logs are from Peterson et al. (2012). The calibrated ${ }^{14} \mathrm{C}$ date (cal) in FAHY is projected from an auger gouge- core site (A15) in the central marsh area, as shown in Figure 6. 


\subsection{Historic Alterations of the Coquille River Estuary Floodplain Wetlands}

Using historic wetland data (1857-1872), Patricia Brenner mapped as much as 10,100 hectares of floodplain wetlands, dominated by timbered swamp or wooded bottomlands, in the lower Coquille River valley (Ecotrust, 2019). A recent survey (1982) of the floodplains yielded only 5,700 hectares of wetlands, including emergent grasses, or upland prairies, swamps, and tidal/flood-discharge channels. The large decline in wetland area was largely due to extensive diking, draining, and filling for agricultural purposes. The natural floodplain wetlands in the lower Coquille River valley provide feeding habitat for migrating waterfowl and nursery habitat for endangered juvenile anadromous fish species, including chinook, coho, and steelhead, among others (ODFW, 1979; 1998). Only about five percent of the inter-tidal wetlands in the Coquille Estuary remain undiked (USFWS, 2019a). Efforts are currently underway to rehabilitate available altered wetlands back to conditions favorable for wildlife habitat, such as at Winter Lake near Coquille, Oregon (The Nature Conservancy, 2019) (Figure 2A). However, the Bandon Marsh and Ni-les'tun Unit restoration projects (2002-2011) were amongst the first in the Coquille Estuary, after the Bandon Marsh National Wildlife Refuge was established by the U.S. Congress in 1983 (USFWS, 2019a). Alterations of the Ni-les'tun Unit floodplain were made, beginning in the early 1900s, to improve seasonal pasturage for dairy and beef cattle grazing. Coquille Estuary channel-bank dikes (dredge-fill) and storm flood/tide gates, respectively, were installed along the Coquille Estuary channel bank and small tidal creek outlets (Figure 3). Semi-diurnal tidal range (MHHW-MLLW) is $\sim 2.0 \mathrm{~m}$ in the adjacent shallow (vertically-mixed) Coquille Estuary channel ( $\sim 5 \mathrm{~m}$ thalweg depth) (ODFW, 1979). The smallest drainage channels in the central Ni-les'tun marshes were filled-in and rectilinear drainage ditches were constructed to divert flood waters to the floodgatecontrolled drainage ditches (USFWS, 2019b). A fill-dike was constructed across a northern portion of the floodplain marsh to permit vehicle access along the North Bank Ln roadway.

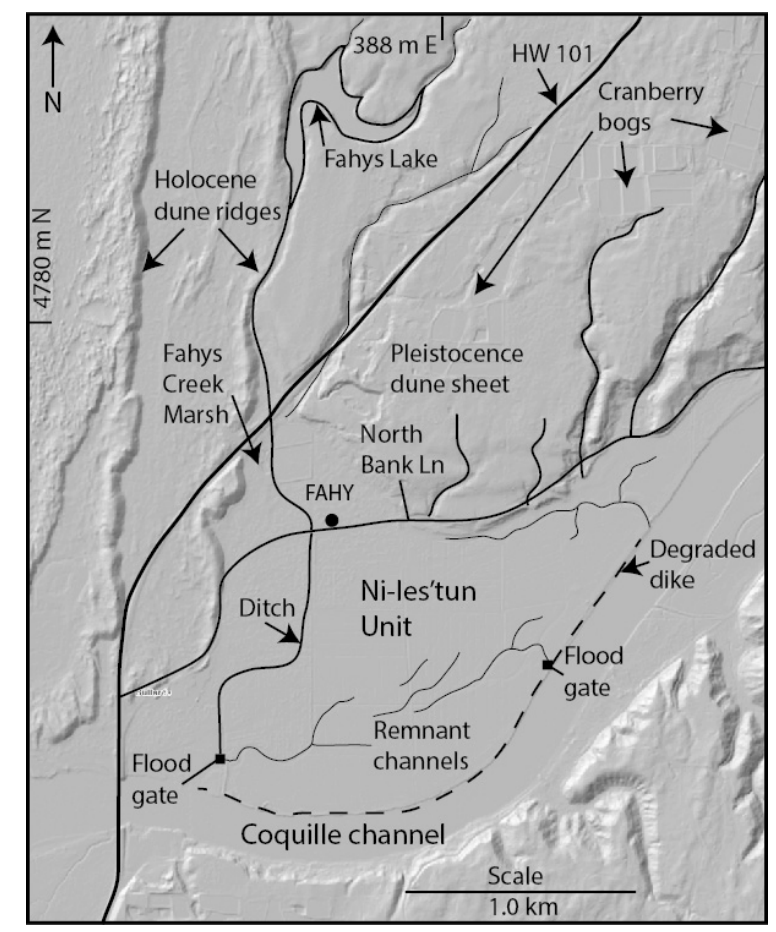

Figure 3. Hill-shaded bare-ground Lidar DEM of the Ni-les'tun Unit floodplain

The Ni-les'tun floodplain ( $\sim 200$ hectares surface area) is shown including the Ni-les'tun Unit and the Fahys Creek marsh, located on either side of the North Bank Ln roadway (bold line). Floodplain alterations include 1) in-filled drainage channels (lines), 2) riverbank dike (bold dashed line), 3) constructed drainage ditch (bold line), and 4) storm flood gates at tidal creek entrances (solid squares). The FAHY vibracore site (solid circle) is shown in the Fahys Creek marsh. The rehabilitated Ni-les'tun Unit is bounded to the north by hill-slopes and the North Bank Ln dike and to the south and east by the Coquille River estuary channel. Seasonally flooded cranberry bogs (top of map) are developed in late-Pleistocene dune sheet deposits. Holocene dune ridges (left side of map) barrage Fahys Lake, a window lake in the upland dune sheet aquifer. Headward eroded gullies (bold lines) locally drain the hill-slope aquifer (southward) to the adjacent Ni-les'tun floodplain. Lidar base map (2009) is from DOGAMI (2019b). 


\subsection{Preliminary Surveys for Wetland Restoration}

Restoration planning for the Ni-les'tun Unit included vegetation and surface feature surveys (2002) to establish latest-prehistoric floodplain conditions. Low marsh (salt tolerant) vegetation (Frenkel et al., 1981), such as pickleweed (Salicornia), was found to occur locally in the central marsh area, some 300-400 m landward of the diked channel bank/tidal creek entrances (Figure 4A). Perennial rush and sedge swamps (freshwater) were found to occur along the marsh back-edges that are adjacent to hillslopes and narrow gullies, and within the Fahys creek drainage outlet. These perennial swamps are developed in supratidal sites ( $>2.5 \mathrm{~m}$ elevation), which occur above the reach of the highest summer tides, but they are within reach of Coquille River/Estuary overbank floods (Figure 4B). To reconcile these unexpected results, several hydrogeomorphic studies of the Ni-les'tun floodplain were initiated in 2003 and 2005, as outlined below. These studies concluded with preliminary water-quality testing of reconstructed floodplain channels in 2011 and 2012 (Beard, 2013).

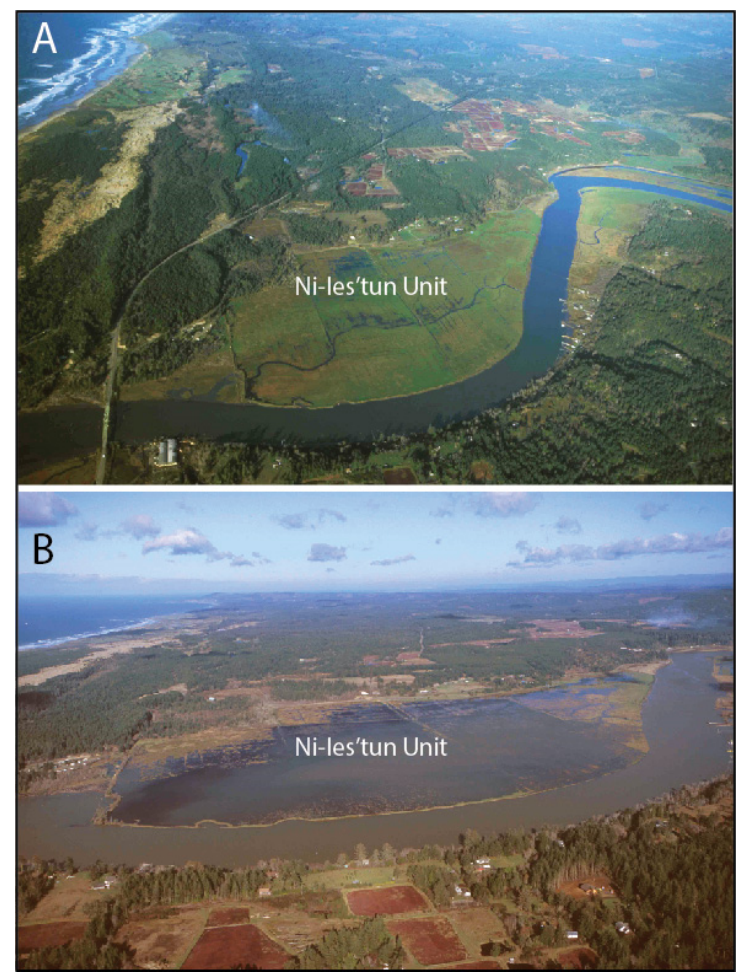

Figure 4. Oblique air photographs of the Ni-les'tun Unit, as viewed to the north

Part A. The Ni-les'tun Unit floodplain at low river level (summer) is shown with emergent vegetation and waterfilled remnant drainage channel(s) (marsh center), prior to removal of channel bank dikes and storm/tidal creek gates. Part B. During peak Coquille River flooding (winter) the Ni-les'tun Unit floodplain was submerged by flood overtopping of existing (degraded) channel bank dikes and storm/tide gates. Photos are from the Bandon Marsh National Wildlife Refuge (curtesy of Dave Pitkin, 2005).

\section{Methods}

Subsurface hydrogeomorphic studies in the Ni-les'tun Unit began in 2003 with GPR imaging of shallow floodplain deposits, including 1) remnant latest-prehistoric discharge/tidal channels, 2) approximate depths of GWS reflections, and 3) distinctive signal interruptions by subsurface salinity intrusion. GPR has been used in other peaty wetlands to establish depth to the GWS (Lowry et al., 2009). Fort this study, a Sensors and Software ${ }^{\mathrm{TM}}$ pulseEKKO 1000v GPR system was used with $100 \mathrm{MHz}$ antenna to collect GPR profile data, with $\geq 4$ digital stacking at $0.5 \mathrm{~m}$ step intervals (Figure 5A). Data post-processing with AGC gain control (Jol and Bristow, 2003) and calibrated mud and muddy-sand signal velocities of $\left(0.07 \mathrm{~m} \mathrm{~ns}^{-1}\right)$ yielded signal return penetrations of $\sim 4 \mathrm{~m}$ depth subsurface. Ground-truthing of buried channel cut-and-fill features was performed with continuous auger gouge-coring to basal channel lag (woody debris) deposits. Auger gouge-core site elevations are from Lidar 2009 bare ground DEM (reported vertical error $\pm 0.1 \mathrm{~m}$ ) (DOGAMI, 2019b). 


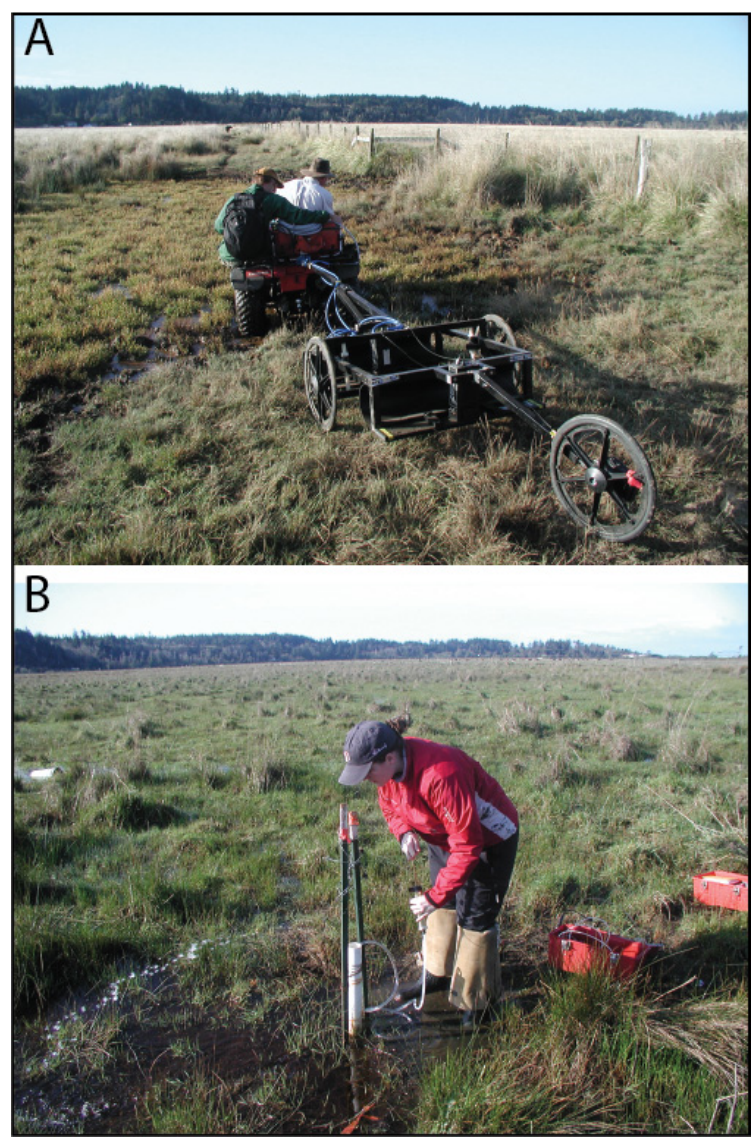

Figure 5. Field work in the Ni-les'tun Unit

Part A. Photograph of the ground penetrating radar (GPR) system with $100 \mathrm{MHz}$ antennae, as mounted on a carbon fiber trailer. Operators, riding on the all-terrain-vehicle, record GPR data and line segment positions from postprocessed global positioning system (GPS) ( $\pm 2 \mathrm{~m}$ estimated error). An odometer wheel triggered the GPR at rolling shot point step distances of $0.5 \mathrm{~m}$. Part B. Photograph of a piezometer well, as used for monitoring 1) shallow groundwater water level (phreatic surface) and 2) water quality, including temperature, conductivity, $\mathrm{pH}$, and dissolved oxygen (DO). Piezometers were top-sealed to assure that well waters were in equilibrium with insitu groundwater conditions during testing.

Following preliminary GPR mapping of GWS gradients and apparent subsurface salinity intrusions, a total of 10 bottom-screened point-tipped piezometers (1.5-2.0 m depth subsurface) were driven into tight-fitting auger holes (2005) for seasonal monitoring of shallow groundwater conditions (Figure 5B). The piezometer exterior collars were sealed with mud/grout slurry. Piezometer tops were sealed with rubber clamp gaskets. Piezometer well heads were leveled-in to the NAVD88 datum by surveyors (vertical error $\pm 1 \mathrm{~cm}$ ). Piezometer water levels were recorded by electronic water meter (phreatic surface depth $\pm 1 \mathrm{~cm}$ ). Shallow groundwater hydrogeochemistry in sealed piezometer wells was measured with a micro-pump and constant through-flow cell $\left(\sim 15 \mathrm{ml} \mathrm{min}^{-1}\right)$, using a ThermoOrion 635 MultiProbe and HP Pocket PC PDA data logger. The Orion multiprobe was used to measure temperature, conductivity, and $\mathrm{pH}$. The multi-probe $\mathrm{pH}$ sensor was calibrated with two known $\mathrm{pH}$ buffer solutions of $\mathrm{pH} 4$ and $\mathrm{pH} 7$ at each piezometer site prior to well sampling. Dissolved oxygen was qualitatively estimated (minimum thresholds) with CHEMets DOK-7501 kits in the field. Late winter sampling occurred in early March due to site accessibility (overbank flooding) issues.

To better understand the potential shallow groundwater flow in the Ni-les'tun Unit floodplain, deeper core sampling was undertaken with a track-mounted geoprobe (model 6620DT). Geoprobe site elevations are from Lidar 2009 bare ground DEM (reported vertical error $\pm 0.1 \mathrm{~m}$ ). Continuous core sections were recovered and archived in core liners (1.5 m length, $2.5 \mathrm{~cm}$ internal diameter) to logged depths of 5-8 m subsurface. Representative geoprobe core sections were sampled and analyzed for grain size, bulk density, porosity, and hydraulic conductivity (permeability) or 'K' (Dingman, 1994). Porosity and hydraulic conductivity were measured 
with a $1000 \mathrm{ml}$ cylindrical constant-head permeameter (ASTM, 2006), using geoprobe samples that were homogenized and then remolded to initial core sample (in-situ) compaction or unconfined shear strengths.

Coincident with floodplain channel construction and Coquille Estuary channel bank dike and flood/tide gate removal 2009-2011 (USFWS, 2019b), selected channel sites were tested for water quality parameters in 2011 and 2012 (Beard, 2013). Water quality testing was performed at $0.3 \mathrm{~m}$ water depths (near surface) with Vernier TM sensors, including temperature, conductivity, $\mathrm{pH}$, and dissolved oxygen. Channel bank site elevations are from Lidar 2009 bare ground DEM (reported vertical error $\pm 0.1 \mathrm{~m}$ ).

\section{Results}

In this section we describe 1) morphostratigraphic studies of the latest-prehistoric floodplain deposits and incised discharge channels, 2) spatial variability of shallow aquifer hydrogeologic conditions, and 3) spatial variability of shallow groundwater hydrogeochemical parameters in the Ni-les'tun Unit floodplain.

\subsection{GPR Profiling and Auger Gouge-Coring in The Ni-les'tun Unit Floodplain}

The scale and distribution of latest-prehistoric (buried) channel features in the Ni-les'tun Unit were investigated by continuously-towed GPR profiling (Figure $5 \mathrm{~A}$ ). The combined GPR track line distance $(11.1 \mathrm{~km})$, in 50 orthogonal profiles, yielded a total of $\sim 22,200$ shot points (0.5 m step distance) (Figure 6). Signal return penetrations of $\sim 4 \mathrm{~m}$ depth subsurface were sufficient to identify shallow channel cut-and-fill features. Analyzed channel parameters included 1) channel positions (distances in georeferenced track lines), 2) channel 'apparent' widths, relative to GPR line orientations, and 3) channel depths, as based on basal high-amplitude reflections. Paleo-tidal channels, located near the Coquille River bank (at least 6 in number), reached up to $35 \mathrm{~m}$ in width and at least $2.5 \mathrm{~m}$ in basal depth (Figure 7A). No such larger channel features were found in floodplain interior areas. Smaller channel crossings (5-10 $\mathrm{m}$ in 'apparent' width and 1.0-2.5 $\mathrm{m}$ depth subsurface) were present (Figure 7B), though uncommon ( $\mathrm{n}=15$ identified), throughout the floodplain interior (Figure 6). The greater size of the paleotidal creek entrances along the Coquille channel bank are not unexpected, as modern tidal creek entrances typically widen and deepen at confluences with major tidal channels. In summary, the central interior of the Ni-les'tun Unit likely contained several dendritic networks of small, i.e., narrow and shallow, paleo-drainage/tidal creek channels prior to historic alterations.

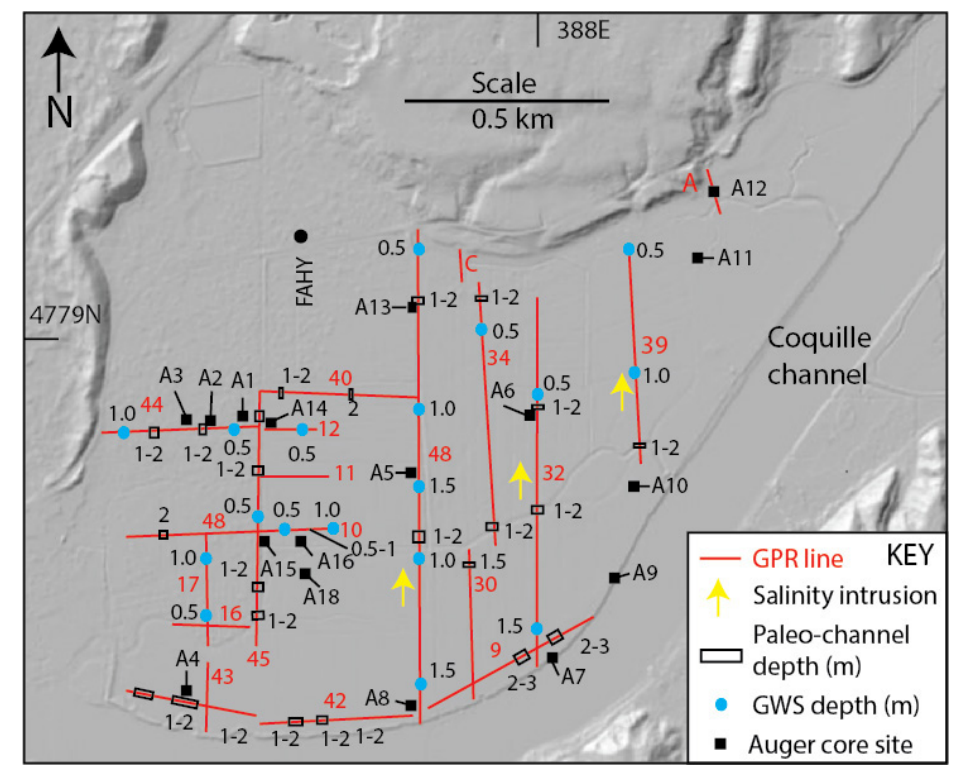

Figure 6. Selected GPR track lines and gouge core sites are shown for the Ni-les'tun Unit

Interpreted GPR profile data include 1) shallow paleo-channel width (box length) and basal depth (m), 2) identified sites of GWS reflection with estimated subsurface depth (m), and 3) maximum landward extent of apparent signal truncation by subsurface salinity. Selected GPR targets were ground-truthed by shallow auger gouge-coring. GWS elevations on the Coquille Estuary channel levees, at the south ends of GPR lines 48 and 32, were from saturated sand depths in auger-gouge cores. Subsurface salinity intrusions in the vicinity of those lines prevented GWS reflection imaging by GPR. Two small paleo-channels near auger gouge-core site A7 were mapped in exposed Coquille Estuary cutbank sections, as salinity intrusion prohibited signal penetration in GPR line 9. 


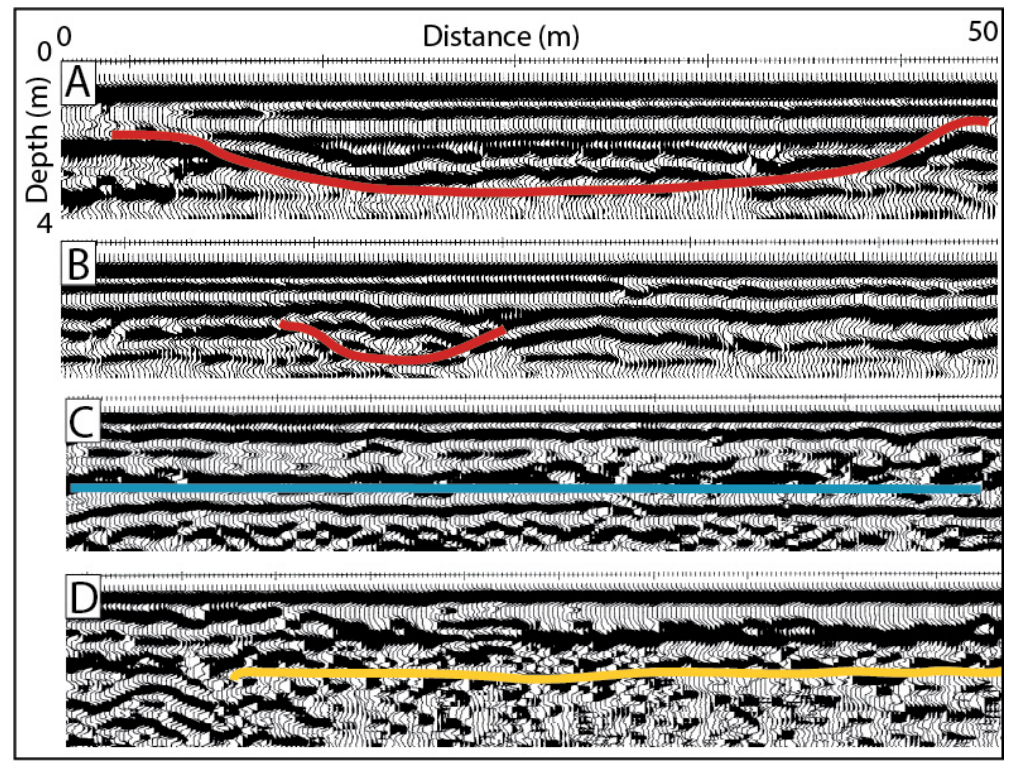

Figure 7. GPR profiles in the Ni-les'tun Unit floodplain

Four GPR profile sections are $50 \mathrm{~m}$ in length and $4 \mathrm{~m}$ in depth. Part A, Larger channel cut-and fill (red line) feature ( $\sim 35 \mathrm{~m}$ in width and $\geq 2.5 \mathrm{~m}$ depth subsurface) in the east end of GPR line 42 . Part B, Smaller channel cut-and-fill (red line) feature (5-6 m width and 1-2 m depth) in GPR line 30. Part C, Ground water surface (blue line) reflection at $\sim 2.0 \mathrm{~m}$ depth below road surface or $\sim 1.5 \mathrm{~m}$ depth below adjacent marsh surface in north-central segment of GPR line 48. Part D, Loss of signal penetration due to subsurface salinity intrusion (yellow line) in south-central segment of GPR line 48. See Figure 6 for GPR track line positions in the Ni-les'tun Unit.

In addition to ground-truthing GPR profile interpretations, auger gouge-coring was performed to constrain the stratigraphic development and relative age of the Ni-les'tun Unit. Auger gouge cores reached 1.0-3.0 m depth subsurface (Figure 8). Recovered core deposits included mud and sand size fractions. Peaty mud or slightly rooted mud dominated the upper $0.2-0.5 \mathrm{~m}$ of most recovered core sections. These wetland topsoils were mottled by FeOHx mineralized root casts. The redoxy-morphic mottling (Birkeland, 1999) is indicative of variable GWS levels in the seasonally submerged floodplain setting. Underlying deposits included sandy mud, muddy sand, or sand. Odors of decomposing organics in some of the water-saturated basal sandy sections in sites A2, A3, A11 and A13, suggested locally reducing groundwater conditions in the shallow floodplain aquifer.

Unlike the protected marsh setting represented by vibracore site FAHY in the Fahys Creek marsh (Figures 2B and 3 ), the broader Ni-les'tun Unit floodplain is generally characterized by one preserved buried marsh (peaty-mud) horizon (Table 1). This shallowest buried peaty horizon is ${ }^{14} \mathrm{C}$ dated to $\sim 290$ cal intercept at $0.8 \mathrm{~m}$ depth in site A15, which corresponds to the last Cascadia megathrust regional rupture at AD1700 (Satake et al., 1996). The $1^{\text {st }}$ buried peaty mud, between 0.3 and $1.1 \mathrm{~m}$ depth in auger gouge-core sites, is widely distributed $(\mathrm{n}=13 \mathrm{sites})$ in the Ni-les'tun Unit. The widespread record of the AD1700 subsided marsh establishes a latest-prehistoric floodplain surface, of $>0.3 \mathrm{ka}$ in age, throughout the Ni-les'tun Unit floodplain. Only three core sites, A3, A8, and A9, include a next older buried peaty horizon, or $2^{\text {nd }}$ buried marsh, presumably corresponding to regional rupture events at either 1.1 ka or 1.3 ka (Darienzo and Peterson, 1995; Atwater et al., 2003). Therefore, most of the Ni-les'tun floodplain wetlands are relatively young $(<1.5 \mathrm{ka}$ in age), leading to the modest record of channel dissections, as indicated by the GPR profiling (Figure 6). 


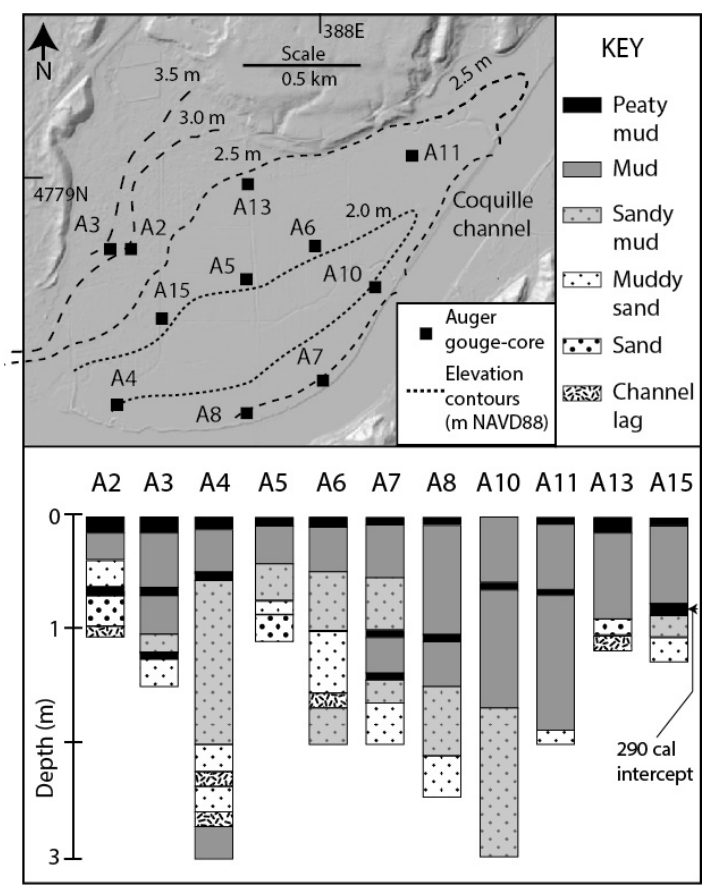

Figure 8. Floodplain elevation contours and selected gouge core logs in the Ni-les'tun Unit

Marsh surface elevation contours ( $0.5 \mathrm{~m}$ intervals) are averaged from bare ground Lidar 2009 DEM using the NAVD88 vertical datum in the Ni-les'tun Unit. The NAVD88 $0 \mathrm{~m}$ datum is $\sim 1.0 \mathrm{~m}$ below mean tide level (MTL) in the study locality. Auger gouge-core logs show that peaty mud generally overlies laminated mud and sandy mud, which both overlie muddy sand or fine sand. Basal channel lag consisted of sand, shell fragments and/or woody debris, as shown in core logs from sites A2, A4, A6, and A13. Saturated sandy deposits occurred below $~ 1$ m depth in sites A3, A13, A14, and A15, and below 1.5 m depth in sites A7, A8, and A11, thereby limiting sediment recovery by auger gouge-coring at greater depths. Strong orders of decomposed organics occurred at basal sand depths in sites A2, A3, A11, and A13. A buried peaty deposit at 0.7-0.8 m depth in site $\mathrm{A} 15$ was ${ }^{14} \mathrm{C}$ dated to $240 \pm 40$ conventional and 290 cal intercept (see Table 1 for laboratory details).

Table 1. Auger gouge-core positions, elevations, depths, and relative ages in the Ni-les'tun Unit.

\begin{tabular}{lllllll}
\hline Core number & UTM-E & UTM-N & $\begin{array}{l}\text { Elevation } \\
(\mathrm{m})\end{array}$ & $\begin{array}{l}\text { Core } \\
\text { depth }(\mathrm{m})\end{array}$ & $\begin{array}{l}\text { Basal sand } \\
\text { depth }(\mathrm{m})\end{array}$ & $\begin{array}{l}\text { Buried marsh no. \& } \\
\text { depth }(\mathrm{m})\end{array}$ \\
\hline A1 & 387308 & 4778824 & 2.2 & 1.5 & 0.9 & $1^{\text {st }}(0.4)$ \\
A2 & 387216 & 4778806 & 2.8 & 1.0 & 0.8 & $1^{\text {st }}(0.7)$ \\
A3 & 387098 & 4778837 & 3.3 & 1.3 & 1.2 & $1^{\text {st }}(0.6) 2^{\text {nd }}(1.0)$ \\
A4 & 387153 & 4778138 & 1.9 & 3.0 & - & $1^{\text {st }}(0.5)$ \\
A5 & 387699 & 4778662 & 2.2 & 1.2 & 0.9 & - \\
A6 & 388043 & 4778802 & 2.2 & 2.0 & 1.0 & - \\
A7 & 388021 & 4778184 & 2.6 & 2.0 & 1.6 & $1^{\text {st }}(1.0) 2^{\text {nd }}(1.4)$ \\
A8 & 387730 & 4778104 & 2.3 & 2.5 & 2.0 & $1^{\text {st }}(1.1)$ \\
A9 & 388203 & 4778380 & 2.7 & 3.0 & 2.0 & $1^{\text {st }}(0.9) 2^{\text {nd }}(1.6)$ \\
A10 & 388259 & 4778606 & 2.4 & 3.0 & - & $1^{\text {st }}(0.7)$ \\
A11 & 388397 & 4774174 & 2.8 & 2.0 & 1.9 & $1^{\text {st }}(0.3)$ \\
A12 & 388454 & 4779367 & 3.4 & 1.2 & 0.8 & $1^{\text {st }}(0.6)$ \\
A13 & 387709 & 4779066 & 2.3 & 1.2 & 0.9 & - \\
A14 & 387398 & 4778847 & 2.0 & 1.5 & 0.5 & - \\
A15 & 387390 & 4778527 & 2.0 & 1.3 & 1.1 & $1^{\text {st }}(0.7){ }^{14} \mathrm{C} \sim 290 \mathrm{cal}$ \\
A16 & 387481 & 4778530 & 1.7 & 2.3 & 2.0 & $1^{\text {st }}(0.5)$ \\
A17 & 387440 & 4778530 & 1.8 & 1.0 & 0.6 & - \\
A18 & 387480 & 4778430 & 1.9 & 1.3 & - & $1^{\text {st }}(0.8)$ \\
\hline
\end{tabular}

Notes: UTM coordinates (10T) are in meters (m). Core site (surface) elevations(m) are relative to the NAVD88 datum. Core depth $(\mathrm{m})$ is equivalent to continuous core length. The tops of apparent basal sand deposits are estimated for depth (m) subsurface. Buried wetland horizons (peaty mud with sharp upper-contacts) are numbered with depth (m). An AMS ${ }^{14} \mathrm{C}$ sample (horizontal needled-twig fragment) is from peaty mud at $76-79 \mathrm{~cm}$ depth in site A15. The reported conventional age ( 1 sigma $=240+/-40 \mathrm{BP})$, InterCal98 calibrated age (280-310 BP), and calibrated intercept age (290 BP) are from Beta Analytic (Beta 221465). 
Estimated depths of GWS reflections in the Ni-les'tun Unit, as imaged by GPR (summer 2003), ranged from $~ 0.5$ to $2.0 \mathrm{~m}$ depth subsurface (Figures 6 and $7 \mathrm{C}$ ). The shallowest GWS depths $(\sim 0.5 \mathrm{~m})$ subsurface $(\mathrm{n}=9)$ were grouped towards the northern side of the floodplain, as bounded by the ancestral valley hillslopes and Fahys Creek marsh. The deepest GWS depths 1.5-2.0 m $(\mathrm{n}=4)$ occurred in the southern and southeastern sides of the floodplain, which are bounded by the Coquille Estuary channel. Summer GPR profiling revealed one other surprising relation of shallow groundwater conditions in the Ni-les'tun Unit. Abruptly terminated signal penetrations in the southeast margins of the Ni-les'tun floodplain (Figure 7D) were attributed to subsurface salinity intrusions from the adjacent Coquille Estuary channel. Such abrupt signal terminations were tentatively traced to the central marsh areas in GPR lines 48, 32, and 39 (Figure 6).

\subsection{Piezometer Well Water Monitoring}

A total of 10 sealed piezometer wells were installed in the Ni-les'tun Unit (Figure 9). The piezometers were monitored (2005-2006) for shallow aquifer hydrogeochemical conditions that represent potential groundwater sources and/or water quality. Standing water depths (phreatic surfaces) were also measured in the piezometers to represent local depth of GWS in the floodplain (Dingman, 1994). Piezometer floodplain surface elevations ranged $1.91 \mathrm{~m}$ to $3.31 \mathrm{~m}$ elevation, and screened bottom depths range from 1.0 to $2.2 \mathrm{~m}$ depth subsurface (Table 2). The Coquille Estuary (channel) and Fahys Creek, were also monitored for their hydrogeochemical conditions. During the winter sampling period (2006), standing or ponded waters on the floodplain surfaces were tested for comparable hydrogeochemical conditions at six of the piezometer sites (P3, P5, P6, P8, P9, and P10).

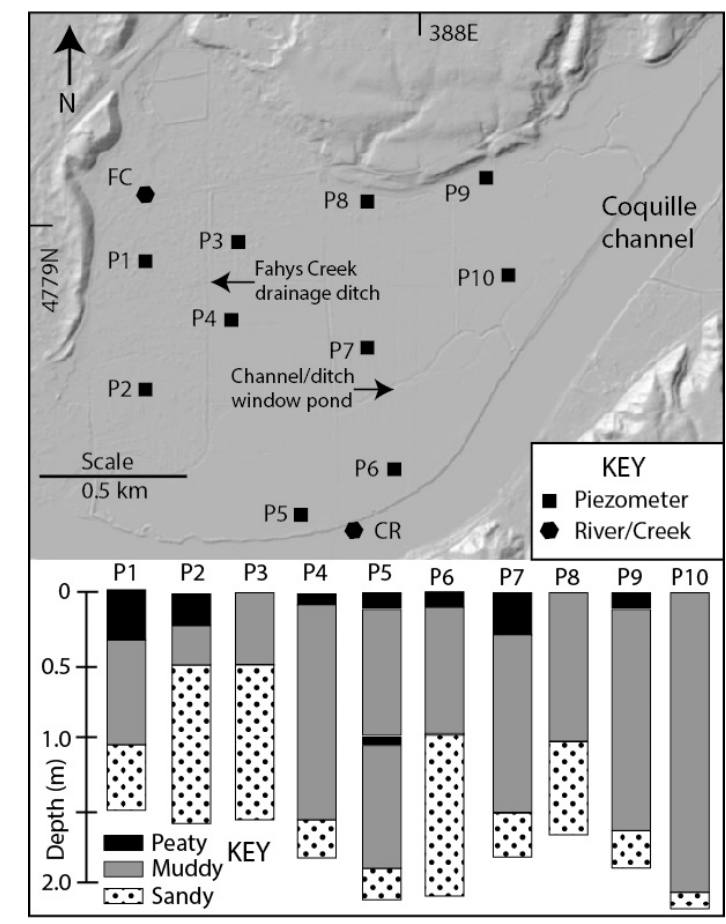

Figure 9. Piezometer monitoring well positions and shallow sediment textures in the Ni-les'tun Unit

Positions of piezometer wells (P1-P10) and Coquille Estuary (CR) and Fahys Creek (FC) testing sites are shown in the Ni-les'tun Unit. Core logs of installed piezometers, including dominant soil textures (peaty, muddy, sandy) as based on visual textural analysis at $25 \mathrm{~cm}$ borehole length intervals. Bottom-screened piezometers were seated in basal sandy units at $\sim 1.5-2.0 \mathrm{~m}$ depth subsurface. Water samples from the Coquille Estuary and Fahys Creek were collected at $\sim 0.3 \mathrm{~m}$ (near-surface) water depth.

Positions of piezometer wells (P1-P10) and Coquille Estuary water (CR) and Fahys Creek (FC) testing are shown in the Ni-les'tun Unit. Core logs of installed piezometers, including dominant soil textures (peaty, muddy, sandy) as based on visual textural analysis at $25 \mathrm{~cm}$ borehole length intervals. Bottom-screened piezometers were seated in basal sandy units at $\sim 1.5-2.0 \mathrm{~m}$ depth subsurface. Water samples from the Coquille Estuary and Fahys Creek were collected at $\sim 0.3 \mathrm{~m}$ (near-surface) water depth. 
Table 2. Piezometer position, elevation and bottom screen depth in the Ni-les'tun Unit

\begin{tabular}{lllll}
\hline Piezometer & UMT-E $(\mathrm{m})$ & UMT-N $(\mathrm{m})$ & Elevation $(\mathrm{m})$ & Depth $(\mathrm{m})$ \\
\hline P1 & 387116 & 4778910 & 3.31 & 1.5 \\
P2 & 387156 & 4778519 & 2.38 & 1.7 \\
P3 & 387398 & 4778981 & 2.33 & 1.6 \\
P4 & 387401 & 4778713 & 1.91 & 1.7 \\
P5 & 387609 & 4778097 & 2.19 & 2.2 \\
P6 & 387839 & 4778210 & 2.24 & 1.7 \\
P7 & 387855 & 4778656 & 1.98 & 1.0 \\
P8 & 387868 & 4779120 & 2.06 & 1.7 \\
P9 & 388242 & 4779180 & 2.02 & 2.2 \\
P10 & 388283 & 4778842 & 2.08 & \\
\hline
\end{tabular}

Notes. Piezometer coordinates are in UTM $10 \mathrm{~N}$ meters $(\mathrm{m})$. Elevations are for adjacent ground surface (m NAVD88), and depths are for screened well bottoms (m depth subsurface).

Piezometer, estuary channel, and Fahys Creek channel analyses included temperature, conductivity, $\mathrm{pH}$, and minimum thresholds of dissolved oxygen (DO) (Table 3). Well water temperature values ranged from 11.3-15.6 ${ }^{\circ}$ $\mathrm{C}$ (summer) to $8.5-16.5^{\circ}$ (winter). Groundwater temperatures (moderate year-round) were not considered to be conservative tracers, so were not measured in all sites. Summer well water conductivities $(n=4)$ showed a much wider range of values $\left(2-16,000 \mu \mathrm{S} \mathrm{cm}^{-1}\right)$ than expected, leading to a denser sampling strategy for the following winter (2006) survey. Winter water well conductivities $(\mathrm{n}=9)$ were $14-18,000 \mu \mathrm{S} \mathrm{cm}{ }^{-1}$. Well water $\mathrm{pH}$ values ranged from 3.10-7.80 (summer) to 2.53-6.80 (winter). The low ends of the groundwater $\mathrm{pH}$ values $(\mathrm{pH} \leq 4.0)$ in piezometer sites $\mathrm{P} 3, \mathrm{P} 8$, and $\mathrm{P} 9$ and low dissolved oxygen $(<1 \mathrm{ppm})$ in sites $\mathrm{P} 1, \mathrm{P} 2, \mathrm{P} 8$, and $\mathrm{P}$, could represent potential stressors to juvenile salmonids (Geist et al., 2006) if those waters were to be intercepted by surface channel flows. The distributions of low-dissolved oxygen and $\mathrm{pH}$ in the northernmost piezometer sites point to origins of the 'low-quality' groundwater from hillslope runoff, interflow, and/or groundwater, as potentially discharged from the upland dune sheets. The dune sheet aquifers in the region are generally associated with reducing or low oxygen conditions (Brown and Newcomb, 1963; Easterly, 2005).

Table 3. Piezometer hydrogeochemistry, summer 2005 and winter 2006 in the Ni-les'tun Unit

\begin{tabular}{|c|c|c|c|c|c|c|c|c|}
\hline $\begin{array}{l}\text { Piezo- } \\
\text { meter }\end{array}$ & $\begin{array}{c}\text { Temp } \\
\left({ }^{\circ} \mathrm{C}\right) \\
\text { Sum ‘05 } \\
\end{array}$ & $\begin{array}{c}\text { Temp } \\
\left({ }^{\circ} \mathrm{C}\right) \\
\text { Win '06 } \\
\end{array}$ & $\begin{array}{c}\text { Conductivity } \\
\left.(\mu \mathrm{S} \mathrm{cm})^{-1}\right) \\
\text { Sum } 05\end{array}$ & $\begin{array}{c}\text { Conductivity } \\
\left.(\mu \mathrm{S} \mathrm{cm})^{-1}\right) \\
\text { Win }{ }^{\circ} 06\end{array}$ & $\begin{array}{c}\mathrm{pH} \\
\text { Sum ‘05 }\end{array}$ & $\begin{array}{c}\mathrm{pH} \\
\text { Win '06 } \\
\end{array}$ & $\begin{array}{c}\text { DO } \\
\text { (ppm) } \\
\text { Sum ‘05 }\end{array}$ & $\begin{array}{c}\text { DO } \\
(\mathrm{ppm}) \\
\text { Win '06 } \\
\end{array}$ \\
\hline P1 well & - & - & - & 140 & - & 6.28 & - & 0.05 \\
\hline P2 well & - & - & - & 18 & - & 6.80 & - & 0.3 \\
\hline P3 surf & - & 8.7 & - & 60 & - & 5.40 & - & $>1$ \\
\hline P3 well & 14.3 & 8.5 & $<10$ & - & 5.25 & 3.52 & - & $>1$ \\
\hline Fahys & & 11.3 & - & 60 & - & 6.00 & & $>1$ \\
\hline P4 well & - & - & - & 190 & - & 6.60 & - & $>1$ \\
\hline P5 surf & - & 14.5 & - & 200 & - & 5.09 & - & - \\
\hline P5 well & 11.4 & 11.8 & 8,000 & 5,450 & 7.16 & 5.07 & - & $>1$ \\
\hline P6 surf & - & 16.5 & - & 1,210 & - & 6.14 & - & - \\
\hline P6 well & 11.3 & 13.5 & 16,000 & 18,780 & 7.80 & 5.59 & - & $>1$ \\
\hline P7 well & - & 12.9 & - & 3,840 & - & 5.49 & - & $>1$ \\
\hline P8 surf & - & - & - & 280 & - & 6.51 & - & - \\
\hline P8 well & 15.6 & 9.9 & 4,130 & 3,760 & 3.10 & 4.07 & - & 0.7 \\
\hline P9 surf & - & - & - & 220 & - & - & - & - \\
\hline P9 well & - & - & - & 8,400 & - & 2.53 & - & 0.5 \\
\hline P10 surf & - & - & - & 14 & - & - & - & $>1$ \\
\hline P10 well & - & - & - & 16,000 & - & 6.16 & - & - \\
\hline Coquille & - & 14.7 & - & 630 & - & 6.05 & - & $>1$ \\
\hline
\end{tabular}

Notes. Testing sites include 1) piezometer wells (P1-P10), 2) the Coquille Estuary (Coquille) and Fahys Creek (FC), and 3) in 'ponded' or standing surface water (surf) at six piezometer sites (P3, P5, P6, P8, P9, and P10) during the winter sampling period (early March 2006). See Table 2 for piezometer coordinates in the Ni-les'tun Unit. The supratidal floodplain top soils ( $>2.0 \mathrm{~m}$ elev. NAVD88) that hosted salinity tolerant vegetation (Salicornia) in the vicinities of P5, P6, and P7 in 2002 (Figures 8 and 9) received their salinity entirely from subsurface salinity intrusion and capillary rise of the saline groundwater in the fully enclosed (diked) central floodplain area. Therefore, the saline topsoil and seasonally ponded brackish water conditions in the supratidal settings of the central marsh do not represent submergence to intertidal levels, but rather subsurface salinity intrusion and capillary rise (summer evaporation) to supratidal elevations. 
Standing or 'locally-ponded' water depths on the floodplain surface were less than $0.25 \mathrm{~m}$ depth during the winter survey. Winter surface water conductivity values were $14-1,210 \mu \mathrm{S} \mathrm{cm}^{-1}$, substantially lower than the piezometer groundwater conductivity levels measured in some piezometers (up to $18,880 \mu \mathrm{S} \mathrm{cm}^{-1}$ ). Winter surface water $\mathrm{pH}$ values were 5.09-6.51, clearly lacking the very-low $\mathrm{pH}$ values found in some of the piezometer groundwater analyses. Several of the winter surface water sites showed $>1 \mathrm{ppm}$ dissolved oxygen, as expected, because surface water in full contact with the atmosphere should contain $\geq 8 \mathrm{ppm}$ dissolved oxygen. In summary, shallow groundwater in the Ni-les'tun Unit is not derived from direct vertical infiltration of surface water, but rather from a variety of subsurface sources that differ greatly in conductivity, $\mathrm{pH}$, and dissolved oxygen. Locally, the shallow groundwater in the Ni-les'tun Unit could compromise surface feature water-quality if sluggish channel flows or stagnant window ponds were to become recharged by low-quality groundwater, particularly during summer periods of low surface water replenishment.

To help establish the timing of shallow aquifer recharge in the Ni-les'tun Unit, the installed piezometers were monitored for seasonal variation in GWS depths (subsurface), which were converted to elevation (m NAVD88) using the piezometer ground surface elevations (Tables 2 and 4). GWS elevations (NAVD88) ranged from 0.61$2.83 \mathrm{~m}$ (summer 2006) to 1.11-2.91 $\mathrm{m}$ (fall 2005) to 1.95-2.99 $\mathrm{m}$ (winter 2006). Seasonal water levels in the constructed Fahys Creek drainage ditch (Figure 3) were observed to vary in accordance with groundwater levels in adjacent piezometers P3 and P4 (Figure 9). The substantial drop in seasonal GWS level in piezometer site P7 from winter ( $2.04 \mathrm{~m}$ elev.) to summer $(0.53 \mathrm{~m}$ elev.) was similarly observed in an adjacent remnant channel/ditch (window pond), confirming GWS control on water levels in adjacent surface water features in the central part of the Ni-les'tun Unit. The drop in GWS elevations between winter and summer (average $\sim 1.0 \pm 0.4 \mathrm{~m}$ for all piezometer sites) represents the seasonal net discharge from the shallow aquifer during the dry summer months. Better understandings of potential sources and mechanisms of groundwater recharge and discharge in the $\mathrm{Ni}$ les'tun floodplain required characterizations of aquifer hydrogeologic properties, as presented below in Section 4.3.

Table 4. Piezometer water level elevations in the Ni-les'tun Unit.

\begin{tabular}{llll}
\hline Piezometer & Fall 2005 $(\mathrm{m})$ & Winter 2006 $(\mathrm{m})$ & Summer 2006 $(\mathrm{m})$ \\
\hline P1 & 2.91 & 2.99 & 2.83 \\
P2 & 1.61 & 2.05 & 0.99 \\
P3 & 1.97 & 2.12 & 1.54 \\
P4 & 1.60 & 1.95 & 0.96 \\
P5 & 1.11 & 2.15 & 0.77 \\
P6 & 1.58 & 2.22 & 0.65 \\
P7 & 1.74 & 2.04 & 0.53 \\
P8 & 1.84 & 2.00 & 1.29 \\
P9 & 1.55 & 2.01 & 1.00 \\
P10 & 1.16 & 2.13 & 0.61 \\
Ave. & 1.71 & 2.17 & 1.12 \\
\hline
\end{tabular}

Notes. Piezometer water heights, relative to the well head, were measured with an electronic water meter $( \pm 1 \mathrm{~cm}$ error), then converted to the NAVD88 datum from the surveyed piezometer elevations. See Table 2 for piezometer positions. Due to marsh surface flooding, and corresponding inaccessibility of some piezometer sites, the fall sampling period extended into latest fall and the winter sampling period occurred during early March.

\subsection{Characterization of Shallow Aquifer Hydrogeologic Units}

To characterize the shallow aquifer under the Ni-les'tun Unit, a track-mounted geoprobe was used to recover continuous core samples for hydrogeologic analyses (Figures 10 and 11). Geoprobe site elevations (2.21-3.84 m) and logged bottom depths $(5.0-8.0 \mathrm{~m})$ are presented in Table 5. Rig mobilization was aided by elevated earth-fill roads and dikes in the marshy floodplain setting. Drive depths and core lengths were compared for each core interval (successive $1.5 \mathrm{~m}$ lengths) to account for loose sand compaction and/or rodding within some sections. Recovered core sections in $1.5 \mathrm{~m}$ drive lengths were stored in sealed plastic core liners, prior to core logging and subsampling. 


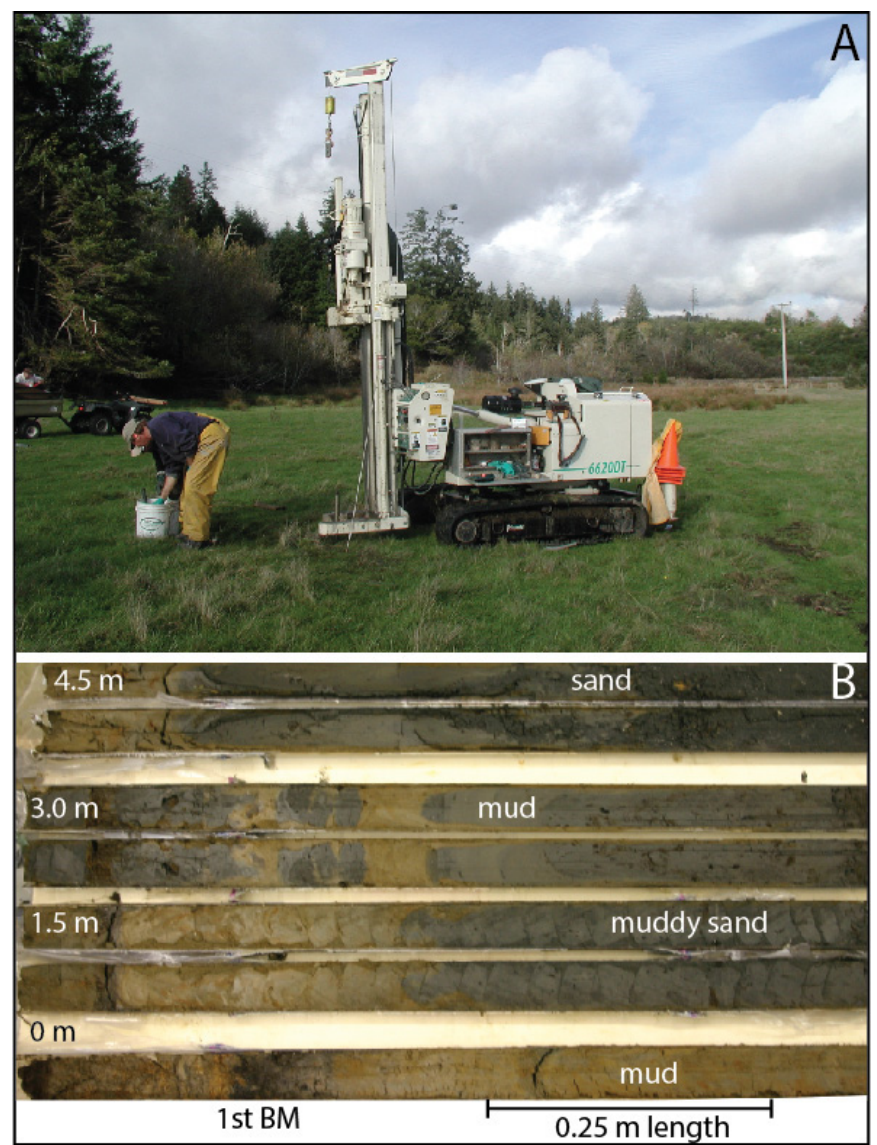

Figure 10. Deeper core sampling by geoprobe in the Ni-les'tun Unit

Part A, A track-mounted geoprobe was used for sediment coring (reaching 5-8m depth) in the shallow aquifer under the Ni-les'tun floodplain surface at site G9. Part B, Top half portions of successive $1.5 \mathrm{~m}$ core sections, starting at $0 \mathrm{~m}, 1.5 \mathrm{~m}, 3.0 \mathrm{~m}$ and $4.5 \mathrm{~m}$ depth, are shown for site $\mathrm{G} 3$ near the Coquille Estuary channel bank. The first buried marsh ( $\left(1^{\text {st }} \mathrm{BM}\right.$ at about $0.2 \mathrm{~m}$ depth) is ${ }^{14} \mathrm{C}$ dated to $290 \mathrm{cal}$ in the nearby auger gouge-core site A15 (Table 1). Representative core samples, $30-50 \mathrm{~cm}$ in length, were homogenized and then remolded for hydrogeologic lab testing. Locations of geoprobe sites (G9 and G3) are shown below in Figure 11.

The shallow aquifer under the Ni-les'tun floodplain surface is generally characterized by 1) muddy units in the uppermost 1.0-1.5 m of depth, 2) underlying units of either sandy mud or muddy sand, 3) basal sand at 3-8 $\mathrm{m}$ depth, and 4) non-contiguous layers of mud at depths below 3 m subsurface in several sites (G1, G2, G5, and G11) (Figure 11). The presence of the deeper mud lenses and an absence of sand/mud accretionary bank laminations, argues against floodplain accretion by major subtidal channel migration. Rather the floodplain appears to have developed from 1) the vertical accretion of a subtidal sand flat to an intertidal mud flat, and then 2) the progradation and episodic vertical accretion of a supratidal floodplain. Shallow buried marsh deposits in sites G3, G5, and G12 confirm the emergence of the barren tidal flat deposits to vegetated wetlands prior to $0.3 \mathrm{ka}$, or the burial age of the $1^{\text {st }}$ buried marsh at AD1700 (Satake et al., 1996). Only one geoprobe site (G12) contained evidence of a $2^{\text {nd }}$ buried marsh, presumed to be $\sim 1.1$ or $\sim 1.3 \mathrm{ka}$ in age, as suggested above in Section 4.1. 


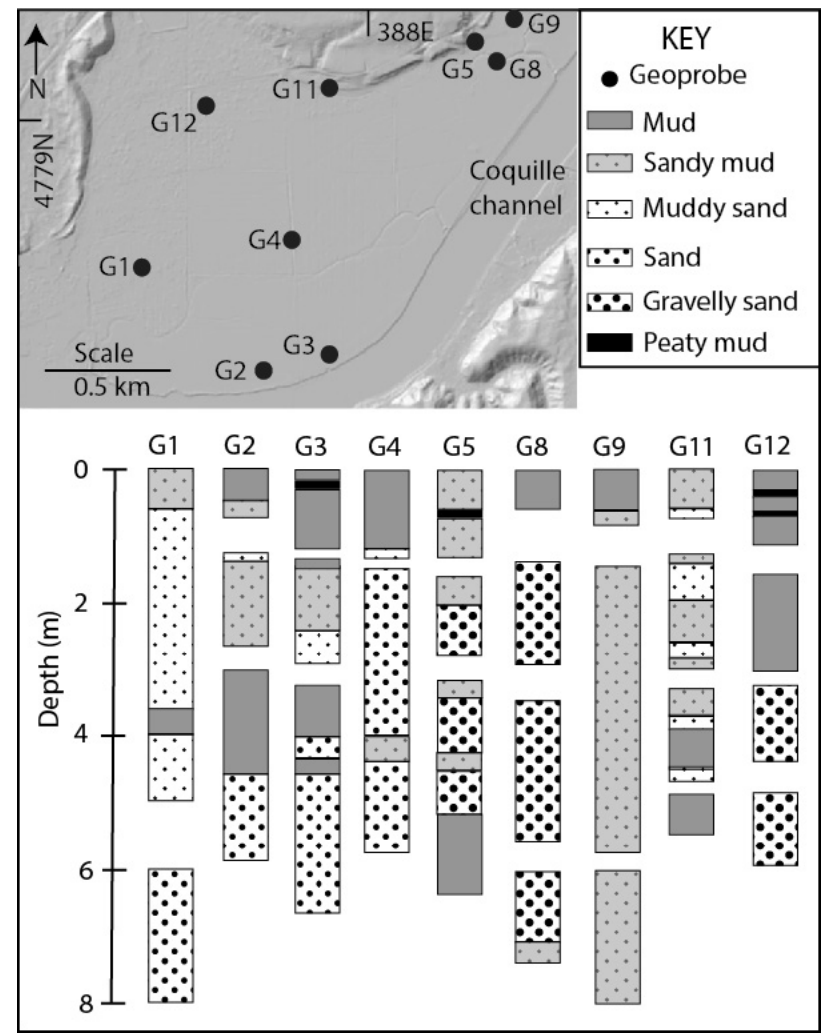

Figure 11. Representative geoprobe sites and core logs in the Ni-les'tun Unit

Representative geoprobe site positions are shown in the Ni-les'tun Unit. Corresponding core logs, reaching 5-8 $\mathrm{m}$ depth subsurface, demonstrate sediment textures or dominant grain sizes in the shallow aquifer. Sand grain-locking with core liner in some geoprobe cores lead to rodding and missing sections (core breaks). Recovered sections were used for hydrogeologic testing, including analyses of grain-size fractions, bulk density, porosity, and hydraulic conductivity $(\mathrm{K})$. Mud is defined as clay and silt $(<0.062 \mathrm{~mm})$ of at least $90 \%$ volume fraction, as calibrated by in-lab rapid settling/decanting of sand fraction volume. Gravel is defined by wet sieving at $>2 \mathrm{~mm}$ size fraction. Intermediate textural compositions are approximated by major and minor volume components, where the adjective is the minor component (Folk, 1980).

Table 5. Positions, elevations and logged basal depths of geoprobe sites in the Ni-les'tun Unit.

\begin{tabular}{lllll}
\hline Geoprobe & UMT-E $(\mathrm{m})$ & UMT-N $(\mathrm{m})$ & Elevation $(\mathrm{m})$ & Depth $(\mathrm{m})$ \\
\hline GP 1 & 387167 & 4778519 & 2.40 & 8.0 \\
GP 2 & 387594 & 4778096 & 2.21 & 6.7 \\
GP 3 & 387842 & 4778208 & 2.27 & 6.0 \\
GP 4 & 387724 & 4778671 & 2.26 & 5.7 \\
GP 5 & 388514 & 4779405 & 3.09 & 6.3 \\
GP 8 & 388525 & 4779385 & 2.80 & 7.5 \\
GP 9 & 388602 & 4779456 & 2.62 & 8.0 \\
GP 11 & 387855 & 4779192 & 3.84 & 5.0 \\
GP 12 & 387379 & 4779184 & 2.42 & 5.5 \\
\hline
\end{tabular}

Notes. Geoprobe coordinates are in UTM 10N meters (m). Ground surface elevations are in m NAVD88. Basal core depths (m) are to logged depths, as corrected for compaction.

Representative core sample analyses of grain size fractions, bulk density, porosity, and hydraulic conductivity in the Ni-les'tun Unit shallow aquifer are shown in Table 6. Gravel is rare in the shallow aquifer, which is dominated by sand (average $81 \mathrm{wt} \%, \mathrm{n}=14)$. The mud size fraction $(<0.062 \mathrm{~mm}$ screen size) makes up a significant minor component (average $14 \mathrm{wt} \%$ ). The shallow aquifer has a large porosity (average 41 volume \%) and moderate hydraulic conductivities $\left(\mathrm{K}\right.$ average $\left.=29 \mathrm{~cm} \mathrm{hr}^{-1}\right)$. However, near surface mud layers, such as in G4 at $0.4-0.9 \mathrm{~m}$ depth and in G1 at $0.2-0.6 \mathrm{~m}$ depth, result in very-low hydraulic conductivities $\left(\mathrm{K}=0.002-0.004 \mathrm{~cm} \mathrm{hr}^{-1}\right)$. These impermeable topsoil mud layers could account for the observed localized ponding of surface water during wet 
winter periods. Relatively high values of hydraulic conductivity $\left(\mathrm{K} \sim 20-140 \mathrm{~cm} \mathrm{hr}^{-1}\right)$ in underlying sandy units should not substantially restrict lateral groundwater flows in the shallow aquifer, as shown in sites G1 at 2.1-2.6 $\mathrm{m}$ depth and 6.4-7.0 m depth, $\mathrm{G} 2$ at 4.6-5.1 $\mathrm{m}$ depth, G3 at 5.4-5.9 $\mathrm{m}$ depth and 6.3-6.8 $\mathrm{m}$ depth, and G11 at 2.3$2.5 \mathrm{~m}$ depth.

Table 6. Aquifer hydrogeologic parameters from remolded geoprobe samples in the Ni-les'tun Unit.

\begin{tabular}{|c|c|c|c|c|c|c|}
\hline $\begin{array}{c}\text { Geoprobe } \\
\text { sample } \\
\text { site/depth (cm) }\end{array}$ & $\begin{array}{l}\text { Gravel } \\
\text { (wt \%) }\end{array}$ & $\begin{array}{c}\text { Sand } \\
\text { (wt \%) }\end{array}$ & $\begin{array}{c}\text { Mud } \\
\text { (wt \%) }\end{array}$ & $\begin{array}{c}\text { Bulk } \\
\text { density } \\
\left(\mathrm{g} \mathrm{cm}^{-3}\right)\end{array}$ & $\begin{array}{c}\text { Porosity } \\
(\%)\end{array}$ & $\begin{array}{c}\text { Hydraulic } \\
\text { conductivity } \\
\left(\mathrm{cm} \mathrm{hr}^{-1}\right)\end{array}$ \\
\hline G1 $10-60$ & 0.0 & 48.2 & 51.8 & 1.05 & 54.6 & 0.004 \\
\hline G1 210-260 & 0.0 & 96.3 & 3.7 & 1.72 & 34.5 & 20.68 \\
\hline G1 637-702 & 0.0 & 99.3 & 0.7 & 1.63 & 41.9 & 141.48 \\
\hline G2 460-510 & 0.6 & 96.8 & 2.6 & 1.62 & 42.2 & 26.32 \\
\hline G2 630-680 & 0.1 & 99.0 & 0.9 & 1.54 & 38.7 & 109.36 \\
\hline G3 545-595 & 1.6 & 96.6 & 1.9 & 1.65 & 38.6 & 24.65 \\
\hline G4 40-90 & 0.0 & 42.0 & 58.0 & 1.54 & 48.5 & 0.002 \\
\hline G4 183-233 & 0.0 & 96.1 & 3.9 & 1.64 & 37.2 & 5.16 \\
\hline G5 210-260 & 37.2 & 60.5 & 2.3 & 1.89 & 30.3 & 9.13 \\
\hline G8 202-252 & 26.6 & 70.8 & 2.5 & 1.80 & 32.0 & 15.93 \\
\hline G9 356-392 & 0.7 & 89.1 & 10.2 & 1.44 & 46.5 & 1.34 \\
\hline G11 160-180 & 0.6 & 94.4 & 5.0 & 1.69 & 35.3 & 4.45 \\
\hline G11 230-250 & 0.8 & 97.7 & 0.0 & 1.63 & 39.3 & 51.10 \\
\hline G12 152-202 & 0.0 & 42.6 & 57.4 & 1.52 & 52.1 & 0.08 \\
\hline Average \pm 1 std & 4.2 & $74 \pm 23$ & $21 \pm 24$ & $1.5 \pm 0.2$ & $44 \pm 9$ & $23 \pm 39$ \\
\hline
\end{tabular}

Notes. Sediment core samples from geoprobe sites $(\mathrm{G})$ at subsurface depths $(\mathrm{cm})$ were analyzed for grain size fractions by wet sieving (weight \%), bulk density in ring samples $\left(\mathrm{g} \mathrm{cm}^{-3}\right)$, and porosity (\%) and hydraulic conductivity or $\mathrm{K}\left(\mathrm{cm} \mathrm{hr}^{-1}\right)$ in $1000 \mathrm{ml}$ cylindrical constant head permeameters.

\section{Discussion}

In this section, relations are presented between 1) shallow aquifer development, 2) sources of groundwater supply, 3) patterns of groundwater flow, and 4) initial analyses of rehabilitated channel water quality in the Ni-les'tun Unit floodplain.

\subsection{Hydrogeomorphology of The Ni-les'tun Unit Floodplain}

The complexities of shallow aquifer dynamics in the Ni-les'tun Unit floodplain derive from 1) multiple recharge sources, 2) stratification of shallow hydrogeologic units, and 3) incised drainage channels that intercept the shallow hydrologic units. In addition to the expected Coquille River/Estuary overbank flooding and infiltration of meteoric water during wet winter periods, the floodplain aquifer is also supplied with water from adjacent hillslope discharge and subsurface intrusion of estuarine saline water (Table 3). The hillslope fresh-water supply is concentrated at the Fahys Creek drainage, which enters the floodplain at the Fahys Creek marsh (Figure 12A). Localized sediment accumulations from the Fahys Creek distributaries yield a topographic mound reaching $\sim 1.5$ $\mathrm{m}$ above the central marsh surface (Figure 8). Subsurface intrusion of saline water from the Coquille Estuary channel occurs along the southeast margin of the floodplain, where the main estuary channel ( $\sim 5 \mathrm{~m}$ thalweg depth) intercepts the floodplain aquifer. A relatively rapid vertical accretion and progradation of the Ni-les'tun Unit floodplain from a sandy tidal flat to a muddy top soil occurred between 0.3 and $\sim 1.1 \mathrm{ka}$ (Figure 11), which is in accordance with reported fish weir ${ }^{14} \mathrm{C}$ dates of $0.6-0.9 \mathrm{ka}$ on the Coquille Estuary channel banks of the Ni-les'tun Unit floodplain (Byram, 2002). The general lack of deeper subtidal paleo-channels in the Ni-les'tun Unit likely results from the young age of the vertically accreted floodplain. 


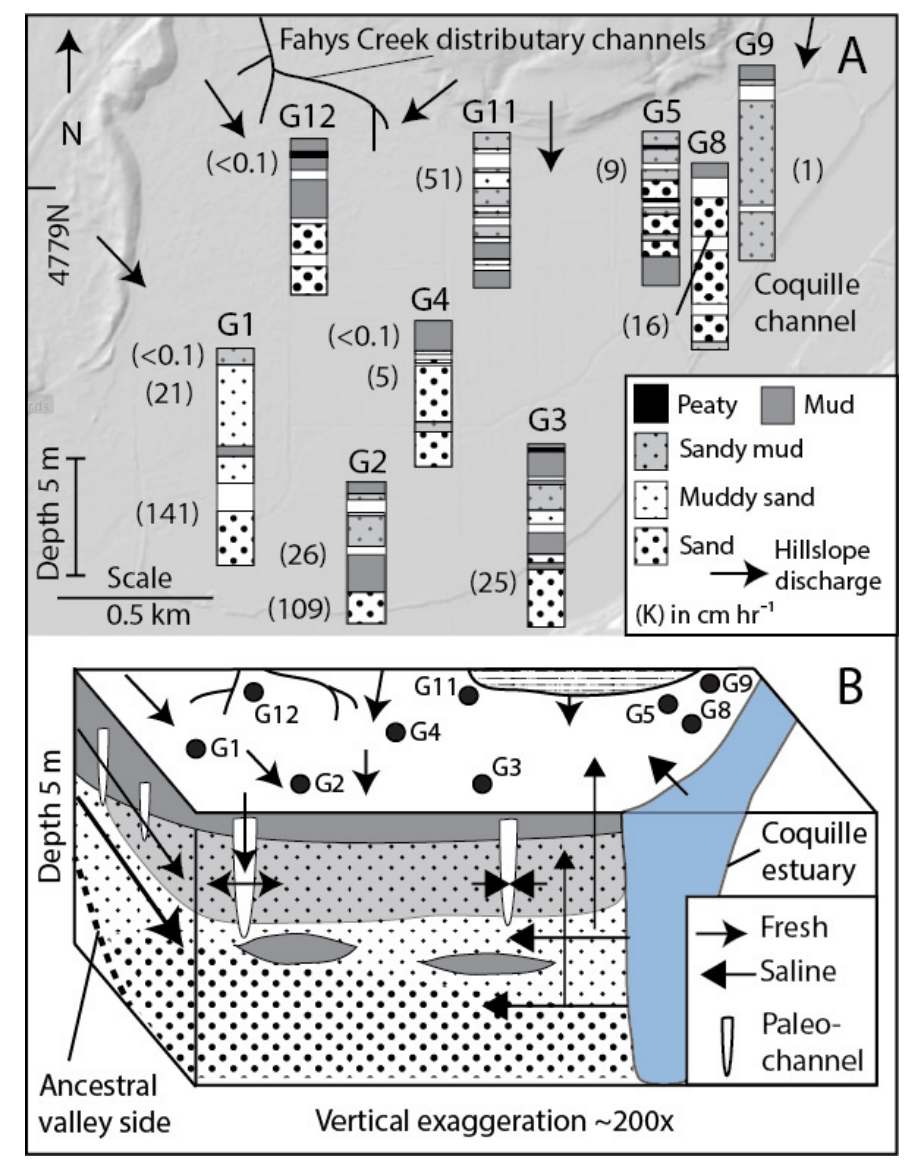

Figure 12. Hydrogeomorphic development of the Ni-les'tun Unit

The hydrogeomorphic development of the Ni-les'tun Unit is shown, including a fence diagram with geoprobe core logs (Part A) and a scaled 3D block diagram of groundwater flow (Part B). A subtidal sand flat vertically accreted to an intertidal muddy sand flat, which transitioned into prograded supratidal wetlands prior to $0.3 \mathrm{ka}$, shown by the $1^{\text {st }}$ buried marsh (peaty mud) in geoprobe sites G3, G5, G12. Very-low hydraulic conductivities in the topsoil muds restricted vertical infiltration. Shallow drainage/tidal channels dissected the floodplain surface in latestprehistoric time. The paleo-channel thalwegs reached sandy mud or muddy sand aquifer units with modest hydraulic conductivities, where lateral groundwater flow crossed under the floodplain surface.

Whereas the near-surface muds $(0-1.5 \mathrm{~m}$ depth) in the Ni-les'tun Unit have very low hydraulic conductivities $\left(\mathrm{K}<0.1 \mathrm{~cm} \mathrm{hr}^{-1}\right)$, the underlying muddy sand/sand units $(2-6 \mathrm{~m}$ depth) yield moderate hydraulic conductivities $\left(\mathrm{K} \sim 10-100 \mathrm{~cm} \mathrm{hr}^{-1}\right)$ (Table 6, Figure 12B). The very-low hydraulic conductivities of near surface mud deposits likely limit or delay vertical infiltration, leading to increased floodplain discharge through surface runoff and/or drainage channels, during wet winter months. The moderate hydraulic conductivities of the underlying sandy hydrogeologic units permit lateral groundwater flows, extending 1-2 km distance (north-south) under the floodplain surface. The subsurface salinity intrusion is likely forced at the Coquille Estuary-floodplain margin under high-tide-level hydraulic heads (Carol et al., 2012), but continues landward by density flow or by lower GWS levels in the central marsh, as lowered seasonally by summer discharge/evaporation (Table 4). The bottoms of small paleo-channels ( $\sim 2 \mathrm{~m}$ depth subsurface) could have intercepted the sandy hydrogeologic units, assuring exchanges between groundwater and surface channel water. Prior to historic alterations of the Ni-les'tun Unit, the paleo-channels crossing the floodplain interior could have 1) been recharged by groundwater during dry summer periods, but then 2) served as sources of localized surface water recharge to the underlying hydrogeologic units during wet winter months of abundant surface water supply.

\subsection{GWS Surface Trends, Salinity Tracers, And Predicted Flow Asymmetries}

GWS elevations from piezometers (Table 4) and selected GPR reflections of GWS (Figure 6) are used to contour GWS trends (summer/fall) in the Ni-les'tun Unit floodplain (Figure 13A). Shallow groundwater is assumed to 
flow perpendicular to the GWS contours, from Fahys Creek marsh ( $\sim 3.0 \mathrm{~m}$ elevation) to the Coquille Estuary channel ( $\sim 1.0 \mathrm{~m}$ elevation or MSL). The corresponding GWS gradients $(0.001-0.002)$ are oriented northwest to southeast on the western side of the Ni-les'tun Unit. However, piezometer well conductivities indicate a reversed direction of groundwater flow on the southeastern side of the floodplain. Summer well water conductivities decreased from $16,000 \mu \mathrm{S} / \mathrm{cm}$ at the channel levee site P6 to $4,130 \mu \mathrm{S} \mathrm{cm}^{-1}$ at the landward site P8 (Table 3). The well water conductivities remained relatively high during the following winter $\left(\mathrm{P} 6,18,783 \mu \mathrm{S} \mathrm{cm}^{-1}\right.$ and $\mathrm{P} 8,3,763$ $\mu \mathrm{S} \mathrm{cm}^{-1}$ ), demonstrating continued subsurface salinity intrusion during conditions of abundant surface water supply. Surface water conductivities at piezometer sites P6 $\left(1,210 \mu \mathrm{S} \mathrm{cm}^{-1}\right)$ and P8 $\left(280 \mu \mathrm{S} \mathrm{cm}^{-1}\right)$ were substantially lower than their corresponding subsurface counterparts, reflecting a surface discharge of freshwater across the floodplain surface during wet winter months.

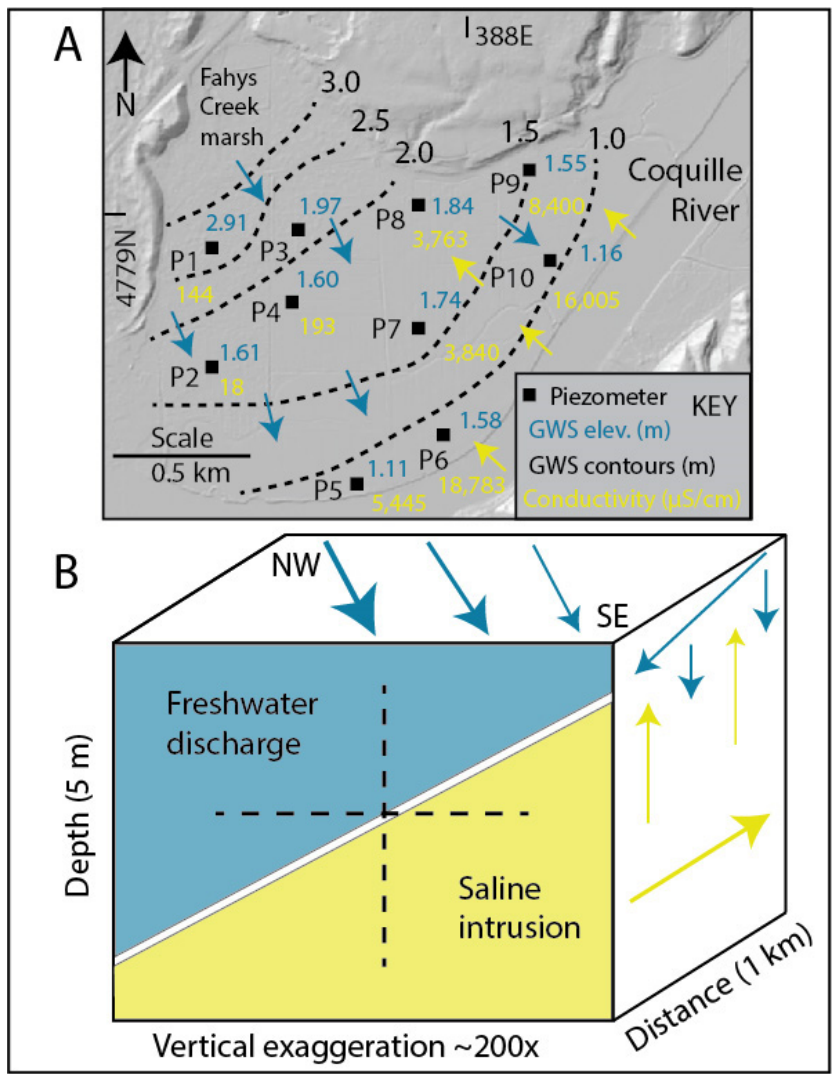

Figure 13. Asymmetric shallow groundwater flows in the Ni-les'tun Unit

Part A, GWS elevations (fall 2005) and well water conductivities (winter 2006) are shown for piezometers (P1P10) in the Ni-les'tun floodplain (Tables 3 and 4). GWS contours are based on piezometer phreatic surfaces, augmented by estimated elevations of GWS reflections in GPR profiles (Figure 6). Predicted freshwater groundwater flows (blue arrows) are perpendicular to GWS contours (dashed lines). Predicted saline intrusions (yellow arrows) are aligned with high conductivity values. Part B, 3D block diagram of four-part model of asymmetric groundwater flows. The freshwater mound in the NW part of the Ni-les'tun Unit (west side) flushes freshwater to several meters depth subsurface along the west side of the floodplain. Salinity intrusion from the Coquille Estuary extends landward in the shallow aquifer in the east side of floodplain but reaches the surface topsoil by capillary rise during summer evaporative conditions.

The relations shown in Figure 13 suggest two asymmetries of general groundwater flows in the Ni-les'tun Unit floodplain. A horizontal asymmetry exists between the western (freshwater dominant) and eastern (saline water dominant) sides of the Ni-les'tun Unit (Figure 13A). A vertical asymmetry is interpreted to exist between near surface flow (freshwater discharge) to the Coquille Estuary channel, and deeper subsurface flow (salinity intrusion) landward, under the Ni-les'tun Unit. These two asymmetries in the shallow groundwater flows are represented by a four-part flow model (Figure 13B), including both the horizontal and vertical flow asymmetries. Seasonal variations in groundwater recharge could add to the spatial complexities of groundwater influences on rehabilitated channels in the Ni-les'tun Unit, as discussed below. 


\subsection{Estimated Seasonal Recharge Volumes}

Estimated values of Ni-les'tun shallow aquifer recharge are based on 1) averaged GWS heights above mean sea level (1.00 m NAVD88) from monitored piezometers (2005-2006) (Table 4), 2) average porosity (41 volume \%) (Table 6), and 3) estimated Ni-les'tun floodplain surface area (200 hectares). The summer recharge volume $\left(0.10 \times 10^{6} \mathrm{~m}^{3}\right)$ (Table 7) is supplied by 1) groundwater and Fahys Creek base flow from the ancestral valley hillslopes, sourced from the large dune sheet aquifers (Figure 2) and 2) from subsurface saltwater intrusion from the Coquille Estuary (Figures 12 and 13). Such complex relations between freshwater supply from dune aquifers and subsurface saltwater supply from a marine source have been reported for other coastal systems (Acworth et al., 1998). In the Ni-les'tun floodplain the fall recharge volume $\left(0.48 \times 10^{6} \mathrm{~m}^{3}\right)$ represents additional water supply, i.e., above base flow, from direct precipitation on the marsh and from hillslope surface runoff and/or interflow. Fall precipitation on the Ni-les'tun marsh ( $40 \mathrm{~cm}$ in the study region) (NOAA, 2019a) could account for nearly $2 \mathrm{x}$ of the net fall recharge. The winter recharge volume $\left(0.38 \times 10^{6} \mathrm{~m}^{3}\right)$ represents additional direct precipitation on the marsh, and hillslope runoff, and Coquille River overbank flooding. For example, the Coquille River gauge height at Coquille, Oregon (Figure 2) increased from 2.0-2.5 m (fall 2005) to $6.7 \mathrm{~m}$ in late December 2005 and early January 2006 (NOAA, 2019b). Brief channel overbank flooding (Figure 4B) was observed on several occasions during the 2005-2006 winter period. However, direct precipitation on the Ni-les'tun marsh $(\sim 90 \mathrm{~cm}$ in the study region) during the winter period could account for $>4 \mathrm{x}$ the winter net recharge (above the fall recharge). Even so, sustained elevated conductivities of piezometer groundwater $3,763-18,783 \mu \mathrm{S} \mathrm{cm}^{-1}$ in the southeastern part of the Ni-les'tun Unit were measured during the winter period (Table 3). Therefore, much of the surface water supply to the Ni-les'tun marsh, from direct precipitation and/or Coquille River/Estuary overbank flooding, did not infiltrate into the shallow groundwater aquifer due to likely subsurface saturation, but rather it drained from the floodplain surface to the Coquille Estuary channel by surface/drainage channel discharge during winter months (Figure 13B).

Table 7. Seasonal recharge volumes in the Ni-les'tun Unit.

\begin{tabular}{|c|c|c|c|c|c|c|}
\hline Season & $\begin{array}{c}\text { GWS } \\
\text { elevation } \\
\text { (m NAVD88) }\end{array}$ & $\begin{array}{c}\text { Increase GWS } \\
(\mathrm{m})\end{array}$ & Summer recharge volume $\left(\mathrm{m}^{3}\right)$ & $\begin{array}{c}\text { Fall } \\
\text { recharge } \\
\text { volume }\left(\mathrm{m}^{3}\right)\end{array}$ & $\begin{array}{c}\text { Winter } \\
\text { recharge } \\
\text { volume } \\
\left(\mathrm{m}^{3}\right) \\
\end{array}$ & $\begin{array}{c}\text { Total } \\
\text { recharge } \\
\text { volume } \\
\left(\mathrm{m}^{3}\right) \\
\end{array}$ \\
\hline Summer & 1.12 & 0.12 & $0.10 \times 10^{6}$ & - & - & - \\
\hline Fall & 1.71 & 0.59 & - & $0.48 \times 10^{6}$ & - & - \\
\hline Winter & 2.17 & 0.46 & - & - & $0.38 \times 10^{6}$ & - \\
\hline Total & & & & & & $0.96 \times 10^{6}$ \\
\hline
\end{tabular}

Notes: Average groundwater surface elevations (GWS elev. m) are from seasonally monitored piezometers (20052006) (Table 4). Mean sea level (MSL) in the lowest reaches of the Coquille Estuary is taken to be $1.0 \mathrm{~m}$ NAVD88 during the late summer period of lowest Coquille River/Estuary stage. The Ni-les'tun floodplain surface area, including the Ni-les'tun Unit and the Fahys Creek outlet marsh, located north of North Bank Ln (Figure 3) is 200 hectares. Summer recharge volume $\left(0.10 \times 10^{6} \mathrm{~m}^{3}\right)$ is the summer GWS elevation above MSL $(0.12 \mathrm{~m})$ as multiplied by floodplain surface area $\left(2.0 \times 10^{6} \mathrm{~m}^{2}\right)$ and porosity $(04 \%)$. Fall recharge volume is fall GWS elevation above summer GWS level multiplied by floodplain surface area and porosity. Winter recharge is the GWS elevation above fall GWS elevation multiplied by floodplain surface area and porosity. Rainfall in nearby Coos Bay (North Bend airport), Oregon (Figure 1), was $40 \mathrm{~cm}$ (fall 2005), $95 \mathrm{~cm}$ (winter 2005-2006), and $3 \mathrm{~cm}$ (summer 2006) (NOAA, 2019a). Late fall and late winter sampling occurred over about one month each due to accessibility issues.

\subsection{Water Quality Testing in The Constructed Channel Network}

Following the initial GPR profiling in 2003 it was recommended that rehabilitation plans for the Ni-les'tun Unit include a network of well-drained branched (dendritic) tidal channels in the central marsh area. Constructed channels were not recommended for the peripheral northern marsh areas where auger-gouge coring indicated reducing groundwater conditions. Such groundwater sources could be low in $\mathrm{pH}$ and dissolved oxygen, as was later confirmed in piezometer well water testing. Inter-channel depressions or window ponds were not recommended for the southeastern marsh areas where GPR profiling indicated subsurface salinity intrusion. Saline groundwater conditions in those areas were later confirmed by conductivity measurements of piezometer water samples. Patches of saline tolerant vegetation (Salicornia) in small depressions indicated saline capillary rise during periods of summer evaporation. Such saline conditions could lead to saline toxicity in the broader marshgrassland top soils and/or shallow window ponds (Beyen and Meire, 2003). In consultation with wetland 
hydrologists from Ducks Unlimited (USFWS, 2019b), the Bandon Marsh National Wildlife Refuge staff designed a network of reconstructed channels in the Ni-les'tun Unit (Figure 14). The channels were connected to Coquille Estuary tidal flow through several ungated tidal creek entrances (Figure 15). Rehabilitation of the drainage/tidal creek channels in the Ni-les'tun Unit (2009-2011) provided an opportunity to test initial water-qualities in the rehabilitated channel network, on a seasonal basis (Beard, 2013). Channel water sampling sites were positioned 1) near previously installed piezometer sites, 2) in marginal areas of expected groundwater input, and 3) at the Coquille Estuary channel bank and in the Fahys Creek distributary channel. Channel bank elevations ranged 1.4$3.2 \mathrm{~m}$ and averaged $2.3 \mathrm{~m}$ NAVD88 (Table 8). Channel depths ranged 1.5-2.5 m depth below bank surfaces, placing channel thalwegs within intertidal flow ( $0-2 \mathrm{~m}$ elevation or $0 \pm 1 \mathrm{~m}$ mean tidal level), following channel network connection to the Coquille Estuary.

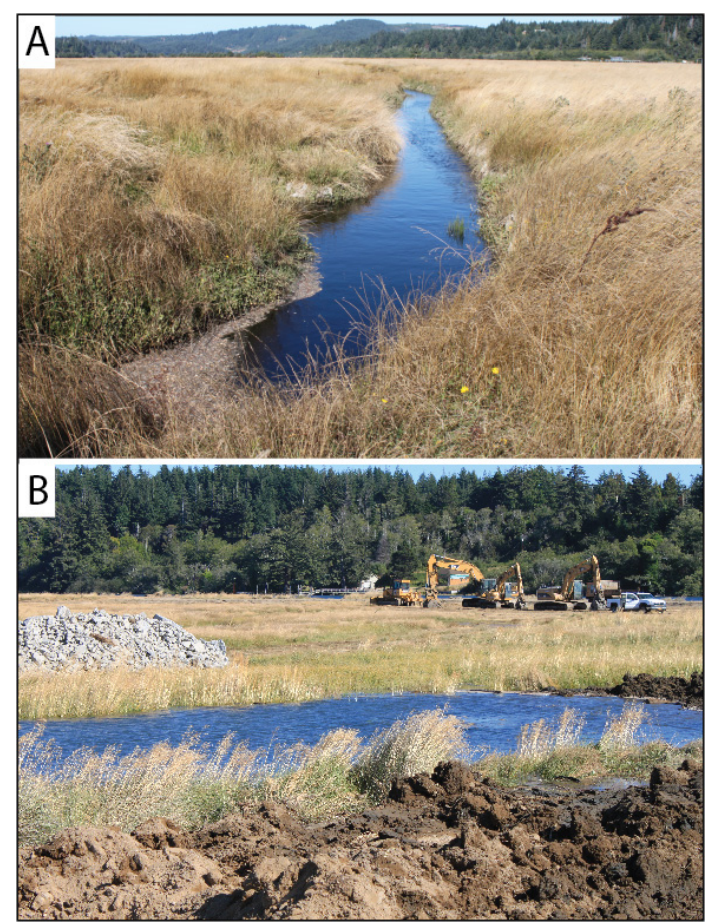

Figure 14. Constructed channels in the Ni-les'tun Unit

Part A, Constructed small channel near sampling site $\mathrm{C} 2$. The channel width is about $2 \mathrm{~m}$ and the depth (from bank) is about $1.5 \mathrm{~m}$. Part B, Larger constructed channel with estimated tidal flow $\left(\sim 0.5 \mathrm{~m} \mathrm{~s}^{-1}\right)$, located near sampling site $\mathrm{C} 10 \mathrm{a}$. Heavy equipment, used for channel network connections and flood/tide gate removal (August 2011 ) is shown in photo background. View is to the south. See Figure 15 for channel sampling site locations.

Table 8. Channel water-quality testing sites in the Ni-les'tun Unit.

\begin{tabular}{lccc}
\hline $\begin{array}{l}\text { Channel testing } \\
\text { Site \# }\end{array}$ & $\begin{array}{c}\text { UTM-E } \\
(\mathrm{m})\end{array}$ & $\begin{array}{c}\text { UTM-N } \\
(\mathrm{m})\end{array}$ & $\begin{array}{c}\text { Bank } \\
\text { elevation }(\mathrm{m})\end{array}$ \\
\hline C 1 & 387751 & 4779124 & 2.3 \\
C 1B & 387731 & 4779190 & 2.6 \\
C 2 & 387759 & 4778446 & 2.0 \\
C 3 & 387754 & 4778057 & 1.8 \\
C 4 & 387748 & 4778348 & 2.1 \\
C 5 & 387840 & 4778459 & 2.2 \\
C 6 & 388057 & 4778874 & 2.1 \\
C 6.2 & 388659 & 4779576 & 2.8 \\
C 7 & 388708 & 4779437 & 1.9 \\
C 8 & 387365 & 4779197 & 3.2 \\
C 9 & 387364 & 4778778 & 2.0 \\
C 10a & 386976 & 4778229 & 2.5 \\
C 10b & 387341 & 4778324 & 1.4 \\
Average & & & 2.3 \\
\hline
\end{tabular}

Notes. Channel site coordinates, in UTM 10N (m) and elevations (m NAVD88) are based on nearest channel bank positions. 


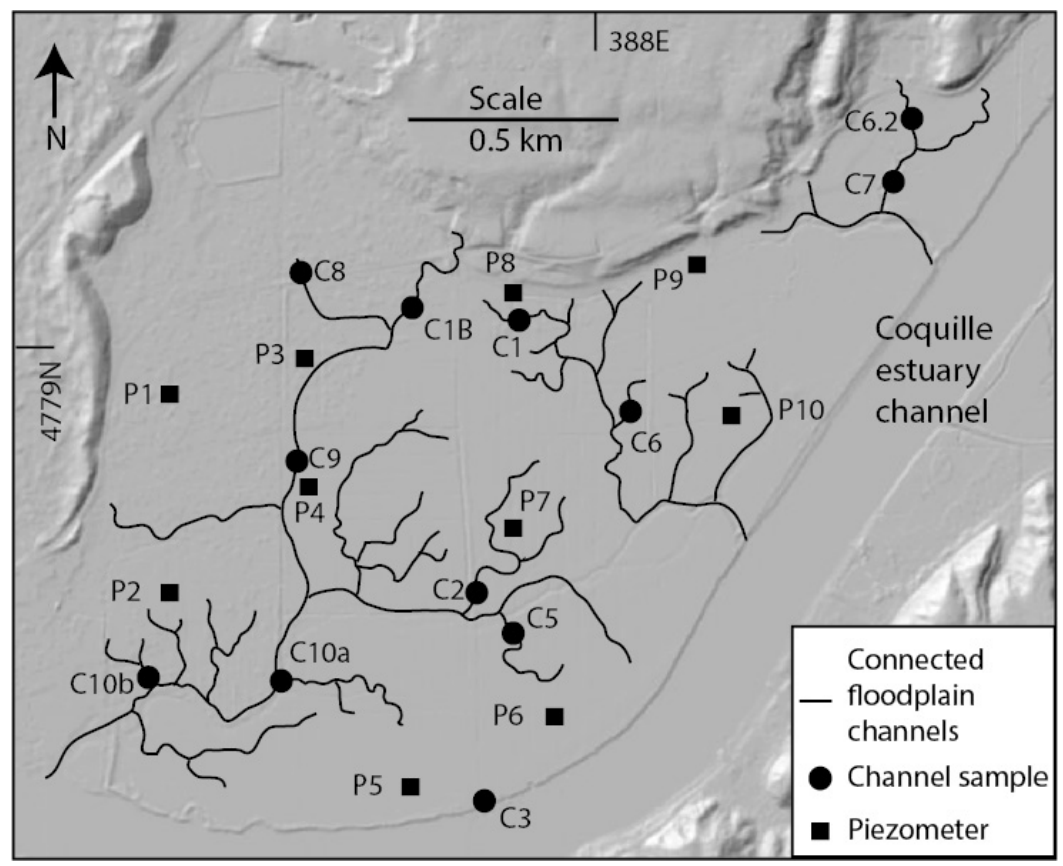

Figure 15. Channel water quality testing sites in the Ni-les'tun Unit

Channel water-quality testing sites were occupied in the summer (2011) and winter (2012) following completion of channel connections, removal of Coquille River bank dikes, and removal of storm/tide gates from tidal creek entrances in the Ni-les'tun Unit floodplain (Beard, 2013). Water quality parameters were monitored in previously installed piezometers in 2005 and 2006 (Table 3).

Following completion of the extended channel network, and removal of storm/tide gates at channel entrances in the Ni-les'tun Unit in 2011 (Figure 15), the newly constructed channels were tested for initial water-quality conditions in summer 2011 and winter 2012 (Beard, 2013). Channel water-quality analysis was done at near surface levels $(0.3 \mathrm{~m}$ water depth) during flood slack water tidal stages to screen for potential low water-quality values. Channel water $\mathrm{pH}$ and dissolved oxygen values could decrease in channel bottoms, relative to the near surface sampling levels used in this study, due to potential groundwater exchange and/or thermohaline stratification. The near surface water levels analyzed in these preliminary surveys were thought to represent relatively well-mixed units within the channel network reaches. Analysis at different channel depths and at different tidal stages for channel water-quality testing is warranted for future extended surveys.

The channel summer water-qualities varied substantially between sites in the Ni-les'tun Unit, with relatively low dissolved oxygen $\left(\leq 5.5 \mathrm{mg} \mathrm{L}^{-1}\right)$ at sites $\mathrm{C} 1, \mathrm{C} 1 \mathrm{Bs}, \mathrm{C} 6, \mathrm{C} 6.2$, and $\mathrm{C} 8$, and high salinity at sites $\mathrm{C} 2, \mathrm{C} 5, \mathrm{C} 6$, and 10A (Table 9). Strong channel flow mixing, or flushing, could alleviate some of the summer water-quality issues, but poorly mixed channel bottoms or isolated window ponds could intercept low quality groundwater conditions during summer periods of low surface-water recharge. Channel winter water-quality was dramatically improved overall, with only two channel sites (C1B and C2) falling below $5.0 \mathrm{mg} \mathrm{L}^{-1}$ dissolved oxygen (Table 10). In summary, most winter channel waters were of sufficiently high-water-quality to support over-wintering juvenile salmonids (Geist et al., 2006), but some summer channel-waters could pose problems to wildlife, depending on the species' water-quality sensitivities.

Three interior channel sample sites (C2, C5, and C6) demonstrated significantly higher conductivities (3,350-5,730 $\left.\mu \mathrm{S} \mathrm{cm}^{-1}\right)$ than the nearby Coquille River/Estuary sample site $\mathrm{C} 3\left(261 \mu \mathrm{S} \mathrm{cm}^{-1}\right)$ during the same winter sampling period (Table 10). Twice-daily tidal flow exchanges with the Coquille Estuary during winter periods of very-low estuary water conductivity, as represented by site $\mathrm{C} 3$, do not account for the brackish water compositions in the interior channel sites $\mathrm{C} 2, \mathrm{C} 5$ and $\mathrm{C} 6$. The channel waters in those reaches reflect significant inputs from saline groundwater, as represented by piezometer sites P6 $\left(18,780 \mu \mathrm{S} \mathrm{cm}^{-1}\right)$ and P7 $\left(3,840 \mu \mathrm{S} \mathrm{cm}^{-1}\right)$ (Table 3 and Figure 15). In the western part of the Ni-les'tun Unit, a low value of summer conductivity in channel site $C 9(1,230 \mu \mathrm{S}$ $\left.\mathrm{cm}^{-1}\right)$ falls well below conductivities in channel sites located down-channel $\left(\mathrm{C} 10 \mathrm{a}\right.$ at $\left.33,510 \mu \mathrm{S} \mathrm{cm} \mathrm{cm}^{-1}\right)$ and upchannel ( $\mathrm{C} 1 \mathrm{~B}$ at 4,060 $\mu \mathrm{S} \mathrm{cm}^{-1}$ ) of the intermediate site C9 (Table 9). The anomalous low conductivity in site C9 during the summer period is attributed to the influence of fresh groundwater supply to the $\mathrm{C} 9$ channel reach from 
the northwest side of the Ni-les'tun Unit (Figure 13), as indicated by piezometer site P3 summer conductivity $(<10$ $\mu \mathrm{S} \mathrm{cm}{ }^{-1}$ ). In summary, the comparisons of water conductivities, as conservative tracers, between channel and nearby piezometer sites confirmed the input of local groundwater supply to the rehabilitated channels in the Niles'tun Unit, during both summer and winter floodplain/aquifer conditions.

Table 9. Connected channel water quality testing (summer 2011).

\begin{tabular}{ccccc}
\hline $\begin{array}{c}\text { Channel } \\
\text { Station \# }\end{array}$ & $\begin{array}{c}\text { Temp } \\
\left({ }^{\circ} \mathrm{C}\right)\end{array}$ & $\begin{array}{c}\text { Conductivity } \\
\left.(\mu \mathrm{S} \mathrm{cm})^{-1}\right)\end{array}$ & $\mathrm{pH}$ & $\begin{array}{c}\text { Dissolved } \\
\text { Oxygen } \\
(\mathrm{mg} / \mathrm{L})\end{array}$ \\
\hline C1 & 14.5 & 177 & 6.85 & 2.0 \\
C1B & 20.5 & 4,060 & 6.78 & 5.4 \\
C2 & 19.3 & 32,610 & 6.27 & 6.5 \\
C3 (Coquille R.) & 15.9 & 34,900 & 6.21 & - \\
C4 & - & - & - & 7.4 \\
C5 & 19.9 & 24,330 & 6.28 & 5.5 \\
C6 & 18.8 & 33,160 & 5.30 & 5.6 \\
C6.2 & 15.0 & 109 & 5.69 & 5.7 \\
C7 & 13.8 & 7,480 & 5.09 & 4.7 \\
C8 (Fas Creek) & 16.7 & 110 & 6.74 & 7.41 \\
C10a & 19.6 & 1,230 & 6.30 & 7.2 \\
Average & 18.5 & 33,510 & 15,610 & 5.7 \\
\hline
\end{tabular}

Notes. The 2011 summer sampling period (September) occurred after channel connections were completed and tide gates were finally removed on August 18, 2011. Sampling was conducted at flood slack water conditions at $\sim 0.3 \mathrm{~m}$ water depth with two-point calibrated sensors ( $\mathrm{pH}$, dissolved oxygen) for each sampling station.

Table 10. Connected channel water quality testing (winter 2012).

\begin{tabular}{ccccc}
\hline $\begin{array}{c}\text { Channel } \\
\text { Station \# }\end{array}$ & $\begin{array}{c}\text { Temp } \\
\left({ }^{\circ} \mathrm{C}\right)\end{array}$ & $\begin{array}{c}\text { Conductivity } \\
(\mu \mathrm{S} \mathrm{cm})^{-1}\end{array}$ & $\mathrm{pH}$ & $\begin{array}{c}\text { Dissolved } \\
\text { Oxygen } \\
(\mathrm{mg} / \mathrm{L})\end{array}$ \\
\hline C1 & 6.2 & 582 & 5.62 & 6.0 \\
C1B & 6.2 & 936 & 5.75 & 4.6 \\
C2 & 6.3 & 5,730 & 5.93 & 1.7 \\
C4 & 8.9 & 261 & 5.66 & - \\
C5 & - & - & 6.03 & 8.1 \\
C6 & 6.9 & 5,310 & 5.76 & 9.3 \\
6.2 & 6.4 & 3,350 & 5.65 & 8.5 \\
C8 & 8.7 & 80 & 5.67 & 8.3 \\
C9 & 9.1 & 350 & 5.89 & 6.4 \\
C10a & 8.7 & 110 & 5.48 & 7.0 \\
Average & 7.2 & 370 & 5.61 & 5.73 \\
\hline
\end{tabular}

Notes. The 2012 sampling period occurred in February. See Table 9 for sampling details.

The performance of the completed Ni-les'tun Unit channel project has been monitored for recruited wildlife since the project completion in 2012 (Silver et al., 2015; Brown et al., 2016). Like other tide-gate removal projects in the region (Souder et al., 2018), the recovery of the rehabilitated Ni-les'tun Unit wetlands has been successful in recruiting desired wildlife species. However, some water-quality issues arose during post-construction summer periods, leading to increased mosquito breeding in the rehabilitated wetlands. Modifications to the constructed channel network, including improved flushing of sluggish tidal creeks and better drainage of isolated inter-channel depressions, helped to alleviate the mosquito breeding problem (USFWS, 2015). Monitoring of the Ni-les'tun Unit floodplain recovery, constructed channel performance, and wildlife recruitment is ongoing. Monitoring results can be obtained from the Bandon Marsh National Wildlife Refuge, Bandon, Oregon.

\subsection{Potential Climate Change Impacts}

Understandings of the hydrogeomorphology of the rehabilitated Ni-les'tun Unit are necessary to predict 'mostlikely' responses of the floodplain wetlands to future climate change. The two expected drivers of future climate change in the Ni-les'tun Unit are prolonged summer droughts and sea level rise. Potential future warming and 
drying in the southwestern Oregon (Dalton et al., 2017) could cause longer summer drought conditions. Decreasing freshwater recharge and increasing evaporation could lead to 1) greater salinities in central marsh top soils, 2) lower GWS depths and corresponding channel water depths in peripheral supratidal channels, and 3) increasing thermohaline stratification of inter-tidal channels/ponds. Increases in topsoil salinity would be most problematic in the southeastern parts of the Ni-les'tun Unit if summer drought conditions were to increase with global warming. Decreases in bottom water-quality in the northern peripheral channels of the Ni-les'tun Unit could occur if channel water recharge becomes increasingly dependent on late-summer hillslope discharge of groundwater with low dissolved oxygen and/or low $\mathrm{pH}$ (Table 3 ).

Predicted sea level rise (possibly $\sim 1 \mathrm{~m}$ within another $100 \mathrm{yr}$ ) (Kopp et al., 2014; Horton et al., 2014; Deconto and Pollard, 2016; Clark et al., 2016; Hansen et al., 2016) could have very different impacts on the rehabilitated Niles'tun wetlands. Rising tidal levels of $0.5-1.0 \mathrm{~m}$ and extended seasonal salinity in the Coquille Estuary could be expected to 1) initially increase the landward extent of the salt marsh in the Ni-les'tun Unit (Frenkel et al., 1981) and 2) increase the surface area of marsh tidal flooding in the Ni-les'tun Unit (Figure 8). The conversion of freshwater grassland to salt marsh could proceed as much by rising subsurface salinity intrusion as by enhanced tidal creek flow (Figure 13B). Depending on the rate of submergence relative to sedimentation from Coquille River/Estuary overbank flooding, the interior flats could remain as upper-intertidal salt marsh or could convert to a lower-intertidal mud flat. The average net sedimentation in the Ni-les'tun Unit, above the $1^{\text {st }}$ buried marsh at $\mathrm{AD} 1700$ is $0.67 \mathrm{~m}(\mathrm{n}=13)$ (Table 1) for the last $\sim 300$ years, including the last $\sim 100$ years of logging in the Coquille River drainage basin. The Ni-les'tun Unit floodplain, generally $\sim 2.25 \pm 0.25 \mathrm{~m}$ NADV88, or $1.25 \pm 0.25 \mathrm{~m}$ MTL (at present), could remain sparsely vegetated with $\sim 1.0 \mathrm{~m}$ of relative sea level rise and $0.3 \mathrm{~m}$ sedimentation during the next century. However, with greater submergence rates and/or lower sedimentation rates, during a similar time interval, most of the Ni-les'tun Unit would convert to lower-intertidal mud flat. Under such a scenario, the higherelevations (>3.0 m NAVD88) and focused hillslope freshwater discharges to the Fahys Creek marsh (Figures 3 and 12A) could provide a small refugia for supratidal marsh habitat in the lowermost reaches of the Coquille Estuary.

\section{Conclusions}

The objectives of this study are to establish whether and/or how groundwater conditions could influence rehabilitated wetland habitats in the fluvial-tidal wetlands of the Ni-les'tun Unit floodplain. The shallow GWS elevations and hydrogeochemical compositions of the shallow groundwater flows were found to locally influence water elevations and water-quality in rehabilitated drainage/tidal creek channels during summer periods of little to no surface water recharge. Specifically, during dry summer periods, sustained groundwater flow from hillslope/creek drainages recharged supratidal channels in the northwestern part of the Ni-les'tun Unit floodplain. Smaller groundwater flows from subsurface intrusion of estuary channel water in the southeastern part of the floodplain probably kept intertidal channel bottoms from 'dying-out' during summer minimum ebb tidal levels. However, groundwater-quality compromised some channel reaches that depended on groundwater recharge during summer conditions of no surface water supply. For example, peripheral channels along the northern floodplain margins were depressed in $\mathrm{pH}$ and dissolved oxygen due to low-quality groundwater supply from upland dunesand aquifers. Though not evaluated in this study, subsurface salinity intrusion and capillary rise, during dry summer conditions, could increase salinity toxicity in isolated inter-channel depressions and/or window ponds in the southeastern part of the floodplain. Perhaps the most important result from this study is the recognition of the complex shallow-groundwater dynamics that underlie the Ni-les'tun Unit floodplain. Understandings of such shallow groundwater flow complexities in other fluvial-tidal floodplains could help designers to optimize for desired outcomes in future projects of floodplain wetland restoration.

\section{Acknowledgements}

The research is financed by the U.S. Fish and Wildlife Service, the Coquille Indian Tribe, and the Bandon Marsh National Wildlife Refuge.

This paper is dedicated to the memory of Dave Pitkin and his enthusiastic efforts to rehabilitate coastal wetland habitats in the State of Oregon. Dave Pitkin provided the initial inspiration for this shallow groundwater study on the Ni-les'tun Unit and assisted with study design and preliminary data interpretation. Dave Ledig provided logistical support for the study and assisted with GPR surveys and piezometer installations. Bill Bridgeland provided assistance with constructed channel mapping and channel water testing schedules. John Baham assembled piezometer well monitoring equipment and trained field staff to perform water quality testing. Randy Van Hoy and Stan Vandewetting assisted with piezometer installation, well surveying, and selection of channel water sampling sites. Katelin Alldritt performed piezometer well water hydrogeochemical monitoring. Amy 
Kocourek collected piezometer well water depth data for the Ni-les'tun Unit (fall of 2005 to the summer of 2006). Markus Johnson and Guss Farmer performed geoprobe coring operations. Chris Beard performed water quality testing in the constructed channels and permeameter analyses of remolded geoprobe core samples. Sarah Doliber and Ray Beard assisted with channel water quality data collection. Kennett Peterson assisted with the editing of early versions of this manuscript. Funding for the hydrogeomorphic studies of the Ni-les'tun Unit were provided by the U.S. Fish and Wildlife Service and the Coquille Indian Tribe. Funding for construction of the sealed piezometers and initial well sampling/ testing equipment was provided by the Oregon Sea Grant NOAA Office of Sea Grant and Extramural Program, U.S. Department of Commerce, under grant \#NA76RG0476 project number R/SD-04, and by appropriations made by the Oregon State Legislature. Field logistical support was provided by the Bandon Marsh National Wildlife Refuge, Bandon, Oregon.

\section{References}

Acworth, I., Jankowski, J., Turner, I., \& Soriano, R. (1998). Interaction Among Coastal Sand-Dune Aquifers, Adjacent Wetlands and Seawater, New South Wales, Australia. In J. V. Brahana, Y. Eckstein, L. K. Ongley, R. Schnider, \& J. E. Moorse, (Eds.), Proceedings of the Joint Meeting of the XXVII Congress of the International Association of Hydrogeologists and the Annual Meeting of the American Institute of Hydrologists on Gambling with Groundwater-Physical, Chemical, and Biological Aspects of Aquifer-Stream Relations (Vol. 28, pp. 461-468).

ASTM. (2006). ASTM Standard D2434-68 "Standard Test Method for Permeability of Granular Soils (Constant Head)". ASTM International, West Conshohocken, PA, 2006. Retrieved from http://www.astm.org

Atwater, B. F., Tuttle, M. P., Schweig, E. S., Rubin, C. M., Yamaguchi, D. K., \& Hemphill-Haley, E. (2003). Earthquake recurrence inferred from paleoseismology. Developments in Quaternary Sciences, 1, 331-350. https://doi.org/10.1016/S1571-0866(03)01015-7

Baldwin, E. M., Beaulieu, J. D., Ramp, L., Gray, J., Newton, V. C., \& Mason, R. S. (1973). Geology and Mineral Resources of Coos County, Oregon, Oregon Department of Geology and Mineral Industries. Bulletin 80, 82.

Beard, C. (2013). Characterization of the shallow geohydrology of the Ni-les'tun Unit, Bandon National Wildlife Refuge (p. 99). M.S. Thesis, Portland State University.

Beyen, W., \& Meire, P. (2003). Ecohydrology of saline grasslands: Consequences for their restoration. Applied Vegetation Science, 6, 153-160. https://doi.org/10.1111/j.1654-109X.2003.tb00575.x

Birkeland, P. W. (1999). Soils and Geomorphology (p. 448). Oxford University Press, New York..

Briggs, G. G. (1994). Coastal crossing of the elastic strain zero-isobase, Cascadia margin, south-central Oregon coast (p. 251). M.S. Thesis, Portland State University, Portland, Oregon.

Brown, L. A., Ewald, M. J., \& Brophy, L. S. (2016). Ni-les'tun tidal wetland restoration effectiveness monitoring: Year 4 post-restoration (2015, p. 53). Corvallis, Oregon: Estuary Technical Group, Institute for Applied Ecology.

Brown, S. G., \& Newcomb, R. C. (1963). Groundwater resources of the coastal sand dune area north of Coos Bay. Oregon: U.S. Geological Survey Water-Supply Paper 1619-D.

Byram, R. S. (2002). Brush fences and basket traps: The archaeology and ethnohistory or tidewater wier fishing on the Oregon Coast (p. 359). PhD. Thesis. University of Oregon. Eugene, Oregon.

Carol, E. S., Dragani, W. C., Kruse, E. E., \& Pousa, J. L. (2012). Surface water and groundwater characteristics in the wetlands of the Ajó River (Argentina). Continental Shelf Research, 49, 25-33. https://doi.org/10.1016/j.csr.2012.09.009

Carol, E., Kruse, E., Mancuso, M., \& Melo, M. (2013). Local and regional water flow quantification in groundwater-dependent wetlands. Water Resources Management, 27, 807-817. https://doi.org/10.1007/s11269-012-0216-9

Clark, P. U., Shakun, J. D., Marcott, S. A, Mix, A. C., Eby, M., ..., \& Plattner, G. K. (2016). Consequences of twenty-first-century policy for multi-millennial climate and sea-level change. Nature Climate Change, 6, 360369. https://doi.org/10.1038/nclimate2923

Custodio, E. (2000). Groundwater-dependent wetlands. Acta Geologica Hungarica, 43, 173-202.

Dalton, M. M., Dello, K. D., Hawkins, L., Mote, P. W., \& Rupp, D. E. (2017). The Third Oregon Climate Assessment Report, Oregon Climate Change Research Institute, College of Earth, Ocean and Atmospheric Sciences, Oregon State University, Corvallis, OR. Retrieved from http://www.occri.net/publications-and- 
reports/third-oregon-climate-assessment-report-2017/

Darienzo, M. E., \& Peterson, C. D. (1995). Magnitude and frequency of subduction-zone earthquakes along the northern Oregon coast in the past 3,000 years. Oregon Geology, 57, 3-12.

DeConto, R. M., \& Pollard, D. (2016). Contribution of Antarctica to past and future sea-level rise. Nature, 531, 591-597. https://doi.org/10.1038/nature17145

Dingman, S. (1994). Physical Hydrology (p. 575). New York: Macmillan College Publishing Company.

DOGAMI. (2019a). Geologic map of Oregon. Department of Geology and Mineral Resources. Retrieved from https:/gis.dogami.oregon.gov/maps/geologicmap/

DOGAMI. (2019b). Lidar. Department of Geology and Mineral Resources. Retrieved from https://www.oregongeology.org/lidar/

Easterly, H. (2005). Characterization of iron-bearing films found on ephemeral pools. Central Coast, Oregon, M.S. Thesis, Portland State University, Portland, Oregon.

Ecotrust. (1996). Coquille Estuary historic wetlands (1857-1872). Ecotrust GIS data in Coastalatlas.net SMMS metadata report. Retrieved from https://www.coastalatlas.net/metadata/CoquilleEstuaryHistoricWetlands (1857-1872).htm

Erwin, K. L. (2009). Wetland and global climate change: The role of wetland restoration in a changing world. Wetlands Ecology Management, 17, 71-84. https://doi.org/10.1007/s11273-008-9119-1

Folk, R. L. (1980). Petrology of Sedimentary Rocks (p. 182). Hemphill Publishing Company, Austin Texas.

Frenkel, R., Eilers, H., \& Jefferson, C. (1981). Oregon coastal salt marsh upper limits and tidal datums. Estuaries, 4, 198-205. https://doi.org/10.2307/1351475

Geist, D. R., Abernethy, C. S., Hand, K. D., Cullinan, V. I., Chandler, J. A., \& Groves, P. A. (2006). Survival, development, and growth of Fall Chinook salmon embryos, alevins, and fry exposed to variable thermal and dissolved oxygen regimes. Transactions of the American Fisheries Society, 135, 1462-1477. https://doi.org/10.1577/T05-294.1

Hansen, J., Sato, M., Hearty, P., Ruedy, R., Kelley, M., ..., \& Lo, K. W. (2016). Ice melt, sea level rise and superstorms: Evidence from paleoclimate data, climate modeling, and modern observations that $2{ }^{\circ} \mathrm{C}$ global warming could be dangerous. Atmospheric Chemistry and Physics, 16, 3761-3812. https://doi.org/10.5194/acp-16-3761-2016

Herrera-Pantoja, M., Hiscock, K. M., \& Boar, R. R. (2012). The potential impact of climate change on groundwater-fed wetlands in eastern England. Ecohydrology, 5, 401-413. https://doi.org/10.1002/eco.231

Horton, B. P., Rahmstorf, S., Engelhart, S. E., \& Kemp, A. C. (2014). Expert assessment of sea-level rise by AD 2100 and AD 2300. Quaternary Science Reviews, 84, 1-6. https://doi.org/10.1016/j.quascirev.2013.11.002

Jol, H. M., \& Bristow, C. S. (2003). GPR in sediments: Advice on data collection, basic processing and interpretation, a good practice guide. In C. S. Bristow, \& H. M. Jol, (Eds.), GPR in Sediments, Geological Society of London (Special Publication 211, pp. 9-27). https://doi.org/10.1144/GSL.SP.2001.211.01.02

Kopp, R. E., Horton, R. M., Little, C. M., Mitrovica, J. X., Oppenheimer, M., Rasmussen, D. J., Strauss, B. H., \& Tebaldi, C. (2014). Probabilistic 21 st and 22nd century sea-level projections at a global network of tide-gauge sites. Earth's Future, 2, 383-406. https://doi.org/10.1002/2014EF000239

Krause, S., Heathwaite, A. L., Miller, F., Hulme, P., \& Crowe, A. (2007). Groundwater-dependent wetlands in the UK and Ireland: Controls, functioning and assessing the likelihood of damage from human activities. Water Resources Management, 21, 2015-2025. https://doi.org/10.1007/s11269-007-9192-X

Lowry, C. S., Fratta, D., \& Anderson, M. P. (2009). Ground penetrating radar and spring formation in a groundwater dominated peat wetland. Journal of Hydrology, 373, 68-79. https://doi.org/10.1016/j.jhydrol.2009.04.023

Meyer, D., \& Posey, M. (2009). Effects of life history strategy on fish distribution and use of estuarine salt marsh and shallow-water flat habitats. Estuaries and Coasts, 32, 797-812. https://doi.org/10.1007/s12237-0099164-X

Moore, W. S. (1999). The subterranean estuary: A reaction zone of ground water and sea water. Marine Chemistry, 65, 111-125. https://doi.org/10.1016/S0304-4203(99)00014-6 
NOAA. (2019a). Daily summaries Station Details, North Bend, Oregon 2005-2006. National Centers for Environmental Information. National Oceanic and Atmospheric Administration. Retrieved from https://www.ncdc.noaa.gov/cdo-web/quickdata

NOAA. (2019b). Flood hydrograph for Coquille River at Coquille, Oregon, December 2005. 2005 Year End Floods, Southwest, Oregon. National Oceanic and Atmospheric Administration. Retrieved from https://www.nwrfc.noaa.gov/floods/dec_2005/dec_flood_rpt.htm

ODFW. (1979). Coquille Estuary Inventory Report Vol. 2 No. 7. Prepared by Oregon Department of Fish and Wildlife or Oregon Land and Conservation Development Commission. Salem, Oregon.

ODFW. (1998). Coquille Basin Fall Chinook and Coho Distributions for 1998. Oregon Department of Fish and Wildlife GIS data in Coastalatlas.net SMMS metadata report. Retrieved from https://www.coastalatlas.net/metadata/FallChinookSalmonDistributionfortheCoquilleBasin,1998.htm; https://www.coastalatlas.net/metadata/CohoSalmonDistributionfortheCoquilleBasin,1998.htm.

Peterson, C. D., Cruikshank, K. M., \& Darienzo, M. E. (2012). Coastal tectonic strain and paleoseismicity in the South Central Cascadia Margin, Oregon, USA. In K. Kostas (Ed.), Natural Disaster Research, Prediction and Mitigation: Earthquakes: Triggers, Environmental Impact and Potential Hazards. NOVA Open Access Publisher, New York. Chapter 1 pp 1-37. ISBN: 978-1-62081-883-1. Retrieved from https://www.novapublishers.com

Peterson, C. D., Stock, E., Price, D. M., Hart, R., Reckendorf, F., Erlandson, J. M., \& Hostetler, S. W. (2007). Ages, distributions, and origins of upland coastal dune sheets in Oregon, USA. Geomorphology, 91, 81-102. https://doi.org/10.1016/j.geomorph.2007.02.005

Satake, K., Shimazaki, K., Tsuji, Y., \& Ueda, K. (1996). Time and size of giant earthquake in Cascadia inferred from Japanese tsunami records of January 1700. Nature, 378, 246-249. https://doi.org/10.1038/379246a0

Silver, B. P., Hudson, J. M., \& Whitesel, T. A. (2015). Bandon Marsh National Wildlife Refuge restoration monitoring. Final report to U.S. Fish and Wildlife Service, Columbia River Fisheries Program Office, Vancouver, WA.

Souder, J. A., Tomaro, L. M., Giannico, G. R., \& Behan, J. R. (2018). Ecological Effects of Tide Gate Upgrade or Removal: A Literature Review and Knowledge Synthesis. Report to Oregon Watershed Enhancement Board. Institute for Natural Resources, Oregon State University. Corvallis, OR. 136. Submitted to Oregon Watershed Enhancement Board in fulfillment of grant \#217-8500-14090.

The Nature Conservancy. (2019). Restoring Tidal Wetlands at Winter Lake. The Nature Conservancy in Oregon. Retrieved from https://www.nature.org/en-us/about-us/where-we-work/united-states/oregon/stories-inoregon/restoring-tidal-wetlands-at-winter-lake/

USFWS. (2015). Bandon Marsh Mosquito Status. Bandon Marsh National Wildlife Refuge. U.S. Fish and Wildlife Service. Retrieved from https://www.fws.gov/oregoncoast/bandonmarsh/Mosquito.html

USFWS. (2019b). Ni-les'tun Tidal Marsh Restoration. The Bandon Marsh National Wildlife Refuge. U.S. Fish and Wildlife Service. Retrieved from https://www.fws.gov/oregoncoast/bandonmarsh/restoration/index.cfm

USFWS. (2019ba). Ni-les'tun Marsh Restoration. Bandon Marsh. U.S. Fish and Wildlife Service. Retrieved from https://www.fws.gov/refuge/Bandon_Marsh/what_we_do/restoration.html

Winter, T. C. (1995). Recent advances in understanding the interaction of groundwater and surface water. Reviews of Geophysics, 33(S2), 985-994. https://doi.org/10.1029/95RG00115

Winter, T. C. (1999). Relation of streams, lakes, and wetlands to groundwater flow systems. Hydrogeology Journal, 7(1), 28-45. https://doi.org/10.1007/s100400050178

\section{Copyrights}

Copyright for this article is retained by the author(s), with first publication rights granted to the journal.

This is an open-access article distributed under the terms and conditions of the Creative Commons Attribution license (http://creativecommons.org/licenses/by/4.0/). 